\title{
Distinguishing Proof and Utilization of Resistance of Insect Pests in Grain Legumes: Progress and Limitations
}

\author{
H.C. Sharma, Jagdish Jaba, and Sumit Vashisth
}

\begin{abstract}
Major food legumes including chickpea, pigeon pea, cowpea, field pea, lentil, faba bean, black gram, green gram, and Phaseolus beans play a vital role in food, nutritional security, and sustainable crop production. Several insect pests damage grain legumes, of which Helicoverpa armigera; Maruca vitrata; Etiella zinckenella; Spodoptera litura and S. exigua; Melanagromyza obtusa; Ophiomyia phaseoli; Aphis craccivora and Bemisia tabaci; Empoasca spp., Megalurothrips dorsalis, and Caliothrips indicus; Mylabris spp.; and Callosobruchus chinensis crusade extensive losses. Appreciable progress has been made in formulating techniques to evaluate germplasm, mapping populations, and genetically modified crops for resistance to insect pests under field and greenhouse conditions. No-choice and dual-choice cage screening techniques, detached leaf assay, and diet incorporation assays have been standardized to screen for resistance to major insect pests in grain legumes. However, some of these techniques cannot be used to screen against stem flies, pod fly, leafhoppers, thrips, and aphids. There is a need to develop methods for mass multiplication of aforesaid insects to undertake precise phenotyping for resistance to these insects. There is a necessity to identify lines with different resistance mechanisms/components of resistance for gene pyramiding to explicate cultivars with the stable source of resistance to insect pests. Prominent levels of resistance to the pod borers have been found in the wild accessions of chickpea,
\end{abstract}

\footnotetext{
H.C. Sharma $(\varangle)$

Dr. Y. S. Parmar University of Horticulture and Forestry, Nauni 173230, India

International Crops Research Institute for Semi-Arid Tropics (ICRISAT),

Patancheru 502324, India

e-mail: hcsharma@ypsuniversity.ac.in

J. Jaba $\bullet$ S. Vashisth

International Crops Research Institute for Semi-Arid Tropics (ICRISAT),

Patancheru 502324, India

e-mail: jaba.jagdish@gmail.com; sumitvashisth_hpau@yahoo.co.in
} 
pigeon pea, and cowpea, which can be exploited to introgress genes to heighten the levels and diversify the basis of resistance to insect pests to build host plant resistance a viable component of pest management in grain legumes for sustainable crop production.

\section{Keywords}

Grain legumes $\bullet$ Host plant resistance $\bullet$ Pod borers $\bullet$ Wide hybridization $\bullet$ Pest management $\bullet$ Wild relatives

\subsection{Introduction}

India is the highest producer and consumer of pulses in the world. Chickpea or Bengal gram (Cicer arietinum), pigeon pea or red gram or tur dal (Cajanus cajan), lentil (Lens culinaris), urdbean or black gram (Vigna mungo), mung bean or green gram (Vigna radiata), lablab bean (Lablab purpureus), moth bean (Vigna aconitifolia), horse gram (Dolichos uniflorus), pea (Pisum sativum), grass pea or khesari (Lathyrus sativus), cowpea (Vigna unguiculata), and broad bean or faba bean (Vicia $f a b a$ ) are some of the most important pulses used as food worldwide. Of these, chickpea, pigeon pea, mung bean, urdbean, and lentil are the major pulses grown in India. Food legumes are cultivated globally on an area of 70 million hectares with a production which is over 78 million tons and an average productivity of $846 \mathrm{~kg} \mathrm{ha-}{ }^{1}$ (FAO 2012). In India, the overall pulse production for the year 2015-2016 was $17.33 \mathrm{mt}$ on an area of 24.89 million ha, with an average productivity of $758 \mathrm{~kg}$ $\mathrm{ha}^{-1}$ (Anonymous 2016). Chickpea is the most predominant pulse crop in India, accounting for $40 \%$ contribution of the total pulse production, followed by pigeon pea (18-20\%), mung bean (11\%), urdbean (10-12\%), lentil (8-9\%), and other legumes (20\%) (Anonymous 2011). Madhya Pradesh (20.3\%), Maharashtra (13.8\%), Rajasthan (16.4), Uttar Pradesh (9.5\%), Karnataka (9.3\%), Andhra Pradesh (7.9\%), Chhattisgarh (3.8\%), Bihar (2.6\%), and Tamil Nadu $(2.9 \%)$ are the major pulse-producing states in India (Anonymous 2009). Food/grain legumes are the primary source of dietary protein and are an integral part of daily diet in several forms worldwide. Pulses supply significant nutritional and health benefits and are known to reduce several noncommunicable diseases such as colon cancer and cardiovascular diseases (Jukanti et al. 2012).

Several biotic and abiotic factors dissemble the production and productivity of grain legumes worldwide, of which insect pests are the predominant. Over the past five decades, significant progress has been made in developing improved cultivars and crop management practices, but there has been little increase in productivity. Grains are damaged by more than 150 species of insect pests, under unprotected conditions and in storage (Clement et al. 2000, Sharma and Upadhyaya 2016). Amid the many insect pests damaging food/grain legumes, the pod borers, Helicoverpa armigera (Hubner) is the most economically important pest of grain legumes in Asia, Africa, and Australia (Sharma 2001). The spotted pod borer, 
Maruca vitrata (Geyer), is another major pest of cowpea and pigeon pea (Jackai and Adalla 1997; Sharma 1998), but it also damages other food/grain legumes, except chickpea and lentil (Sharma et al. 1999). The pod fly, Melanagromyza obtusa Malloch, and pod wasp, Tanaostigmodes cajaninae La Salle, both cause an extensive damage to pigeon pea in India. The leaf miner, Liriomyza cicerina (Rondani), is a significant pest of chickpea in West Asia and North Africa (Weigand et al. 1994). Pea pod borer, Etiella zinckenella Triet, is an important pest of pigeon pea, field pea, and lentil, while the aphid, Aphis craccivora Koch, infests all the food legumes, but it is a major pest of cowpea, field pea, faba bean, and Phaseolus beans. Aphis fabae (Scop.) is a major pest of faba bean and Phaseolus beans, and Acyrthosiphon pisum Harris is an important pest of field pea worldwide.

The whitefly, Bemisia tabaci Genn, infests all the crops, except chickpea crop, but is an important pest of Phaseolus spp. like black gram, and green gram and the defoliators, Spodoptera litura (Fab.) in Asia and S. exigua Hubner in Asia and North America, are occasional pests. Bihar hairy caterpillar, Spilosoma obliqua Walker, is a pest of green gram and black gram in North India, while the red hairy caterpillars, Amsacta spp., damage the rainy season pulses in south central India. Among sapsucking pests, leafhoppers, Empoasca spp., infest most of the food/grain legumes but cause the most economic damage in black gram, green gram, and Phaseolus beans, and in the case of pod-sucking bugs, Clavigralla tomentosicollis Stal., $C$. gibbosa Spin., Nezara viridula L., and Bagrada hilaris Burm. are occasional pests, but extensive damage has been recorded in cowpea in Africa caused by C. tomentosicollis and in pigeon pea in India caused by $C$. gibbosa. Under storage conditions, bruchids, Callosobruchus chinensis L. and C. maculatus Fab, crusade extensive losses in storage in all the food legumes worldwide, and stink bugs (Nezara viridula (L.)) are the major damaging pest in soybean in Brazil (Borges et al. 2011). The pea weevil, Bruchus pisorum L., is an important pest of field pea and most vulnerable to attack major production areas (Clement and Quisenberry 1999; Mendesil et al. 2016).

\subsection{Extent of Losses Due to Insect Pests in Grain Legumes}

In India, insect pests lead to an approximate economic loss in yield of $15.00 \%$ of worth \$2285.29 million (Dhaliwal et al. 2015). Pod borer, H. armigera - the single largest yield shrinking factor in food legumes - causes an estimated loss of US\$ 317 million in pigeon pea and \$328 million in chickpea (ICRISAT 1992). Worldwide, it causes an estimated loss of over $\$ 2$ billion annually, despite over $\$ 1$ billion value of insecticides used to control H.armigera (Sharma 2005). In general, the estimates of yield losses vary from 50 to $100 \%$ in the tropics and $5-10 \%$ in the temperate regions (van Emden et al. 1988). Another pod borer, M. vitrata, causes loss to be US\$ 30 million annually (Saxena et al. 2002). In pigeon pea, yield losses due to pod borer $25-70 \%$, pod fly 10-50\%, Maruca 5-25\%, and pod bug 10-30\% have been reported (Sharma et al. 2010). Soybean aphid (A. glycines) can induce up to 58\% yield losses in soybean crop (Wang et al. 1994) and annually $\$ 2.4$ billion estimated 
losses in yield (Song et al. 2006; Tilmon et al. 2011). Legume flower thrips (LFT), M. sjostedti Trybom, and cowpea V. unguiculata in tropical Africa cause yield losses ranging from $20 \%$ to $100 \%$ (Karungi et al. 2000). The avoidable losses in grain/food legumes at current production levels of 60.45 million tonnes would be nearly 18.14 million tonnes (at an average loss of 30\%), worth at nearly US\$ 10 billion (Sharma et al. 2008).

\subsection{Resistance Screening Techniques}

There are difficulties in screening and choosing for resistance to some important key pests, because of the lack of uniform insect infestations across locations and seasons, and it's also difficult to rear and multiply some of the insect species on artificial diets for artificial infestation. In pigeon pea and chickpea, the screening done by infesting crop plants with ten first-instar larvae and covering with a cloth bag placed all around a wire-framed cage ( $40 \mathrm{~cm}$ in diameter, $45 \mathrm{~cm}$ long) can be used to screen for resistance to the pod borer (Sharma 1998), using no-choice, dualchoice, or multi-choice assays, and plants may be evaluated for insect damage after 15 days of infestation, and this technique used to confirm the resistance under field conditions and find out resistance levels in various cultivars. Most of legume crops under laboratory condition may be screened by using detached leaf bioassay techniques (Sharma et al. 2001b, Sharma 2016) and by adjusting planting date, augmenting insect populations under field conditions, caging the crop plants with insects in the field, grouping of test material according to maturity and height, and tagging the inflorescences at flowering stage (Sharma et al. 2005a). In cowpea manifestation of tolerance to Maruca is affected by different phenology stages of crop (Dabrowski et al. 1983). Plants with five to seven shoots are most desirable to screening for resistance prior to flowering. Taking five eggs per plant, it was easy to differentiate among the resistant and susceptible lines and can be used as selection criteria (Jackai 1982, Oghiakhe et al. 1992a, b). For free and no-choice techniques need to be affirmed under field conditions for screening against major insect pest of legume crops (Echendu and Akingbohungbe 1989). The screening technique for whitefly, B. tabaci, in black gram genotypes may be based on whitefly resistance index (WRI) scores, symptoms, kind, and intensity of leaf injury categorized grades (I-V) for developing tolerant cultivars (Taggar et al. 2012).

\subsection{Identification and Utilization of Resistance to Insects Pests}

Significant effort has been made in recognition of sources of resistance to insect pests, but the orgins of resistance have not been utilized extensively in the crop breeding programs (Clement et al. 1994; Sharma and Ortiz 2002). Varieties with having improved yield factor are more prone to be susceptible to insect pests than the landraces (Lale and Kolo 1998). Lack of strategies for positive selection for 
resistance to insect pests may result in more susceptibility in elite cultivars as compared to the landraces (Shaheen et al. 2006). Some of legume cultivars with resistance/tolerance to insect pests have been identified in pigeon pea, chickpea, cowpea, black gram, green gram, and field pea (Table 5.1). However, the levels of resistance/ tolerance to pod borers are low to moderate but are quite more effective when deployed in combination with newer synthetic insecticides or natural plant products like neem seed kernel extract (NSKE) (Sharma and Pampapathy 2004). Cultivars with multiple resistance to insect pests and diseases will be in greater call for in future because of the needy concerns assorted with chemical control and environmental pollution and the changes in relative importance and severity of damage due to climate change. There is require to break the linkage amid insect pest resistance and susceptibility to diseases; e.g., in case of chickpea and pigeon pea, H. armigeraresistant cultivars are susceptible to wilt diseases (Sharma et al. 2005a).

Screening of various germplasms of chickpea and pigeon pea at ICRISAT (over 15,000 accessions for each crop) has led for identification of a few accessions which shows moderate levels of resistance to H. armigera (Lateef 1985; Lateef and Pimbert 1990). Based on wide testing of pigeon pea lines, such as PPE 45-2, BDN 2, ICPL 4, Bori, and T 21, ICPL 269 and ICPL 88039, early maturity; ICPL 332, ICPL 84060, LRG 41, and ICPL 187-1, medium maturity; and ICP 7035, medium-long maturity and vegetable type were ascertained to be resistant/tolerant to $H$. armigera (Sharma 2009; Srivastava and Joshi 2011). Of these, ICPL 88039 has been widely tested in the Indo-Gangetic Plains in North India, and it found to be suited for rice-wheat cropping system. ICPL 332WR was found to be promising in Andhra Pradesh, while ICP 7035 is opted by the farmers as a vegetable type. The cultivars GP 75, GP 118, GP 233, and GP 253 were confounded to be resistant to M. obtusa, evoking that resistance/tolerance to pod fly is not linked to maturity period and growth type of the genotype/cultivar (Moudgal et al. 2008). The cultivar ICPL 88034 and MPG 679 were showing low Maruca damage (10-25\%) (Saxena et al. 1996).

The breeding efforts in chickpea have developed many Helicoverpa-resistant varieties such as C 235, Anupam, Pant G 114, ICCV 10, JG 74, Dulia, Pusa 261, Vijay, Vishal, ICCV 7, ICCV 10, and ICCL 86103 and were released for cultivation in India (Sharma et al. 2005b). The accessions (ICC 506 EB, ICC 10619, ICC 10667, ICC 4935, ICC 10243, ICCV 95992, and ICC 10817) have been confounded for resistance to $H$. armigera. The cultivar ICC 12475 chickpea showed resistance to $S$. exigua (Shankar et al. 2012). However, progenies of interspecific cultivated chickpea and a wild relative ( $C$. reticulatum) showed high levels of resistance to $S$. exigua. Two accessions of $C$. cuneatum (ILWC 40 and ILWC 187) and 10 accessions of $C$. judaicum with high grades of resistance while 18 lines of $C$. judaicum and 4 lines of $C$. reticulatum and $C$. pinnatifidum have been identified with resistance to leaf miner in chickpea (Singh and Weigand 1994) and germplasm lines, viz., ILC 3800, ILC 5901, and ILC 7738, were identified and registered as sources of resistance to Liriomyza cicerina. Accessions DCP 923, JG 315, BG 1003, and BG 372 showed promise against bruchids, and genotypes GL 88341, BG 360, and RSG 524 were identified as resistant sources against root-knot nematodes (Meloidogyne incognita and M. javanica) (Indian Institute of Pulses Research 2015). 
Table 5.1 Identification and utilization of host plant resistance to insect pests in grain legumes in India

\begin{tabular}{|c|c|c|}
\hline Crop & Genotypes & References \\
\hline \multirow[t]{5}{*}{ Pigeon pea } & $\begin{array}{l}\text { Pod borer, Helicoverpa armigera ICPL 332a, } \\
\text { PPE 45-2, ICPL 84060, BDN 2, ICPL 4, } \\
\text { Bori, T 21, ICP 7035, and ICPL 88039, ICC } \\
\text { 12475, ICC 12477, ICCL 87317, ICCV } \\
\text { 95992, ICPL 98003, ICPL 187-1, LRG } \\
\text { 41ICPL 269, ICP 7203-1, ICPL 84060, ICPL } \\
\text { 87119, ICPL } 332\end{array}$ & $\begin{array}{l}\text { Lateef and Pimbert (1990), Kalariya } \\
\text { et al. (1998), Parsai (1996, 2005), } \\
\text { Sunitha et al. (2008a, b), Sharma } \\
\text { (2009), Srivastava and Joshi (2011), } \\
\text { Kumari et al. (2010a) }\end{array}$ \\
\hline & Legume pod borer, Maruca vitrata & \multirow[t]{2}{*}{ Saxena et al. (1996) } \\
\hline & ICPL 88034 and MPG 679 & \\
\hline & Pod fly Melanagromyza obtusa & \multirow{2}{*}{$\begin{array}{l}\text { Lateef and Pimbert (1990) Moudgal } \\
\text { et al. (2008) }\end{array}$} \\
\hline & $\begin{array}{l}\text { ICP 10531-E1, ICP 7941E1, ICP 7946-E1, } \\
\text { and ICP 7176-5. GP 75, GP 118, GP 233, } \\
\text { and GP } 253\end{array}$ & \\
\hline \multirow[t]{11}{*}{ Chickpea } & Pod borer, Helicoverpa armigera & \multirow{2}{*}{$\begin{array}{l}\text { Dixit (2015), Lateef and Sachan } \\
\text { (1990), Bhagwat et al. (1995), Das } \\
\text { and Kataria (1999), Deshmukh and } \\
\text { Patil (1995), Shankar et al. (2012) }\end{array}$} \\
\hline & $\begin{array}{l}\text { ICC 506, ICC 09314, ICC 738008, ICC } \\
\text { 09104, 09116, ICCL 86105, ICC 14364, } \\
\text { ICCV 7a, ICCV 10a Dulia }{ }^{a} \text {, C 235a, JG 79a, } \\
\text { BJ 256 }{ }^{\mathrm{a}} \text {, JG11, ICCL8611, Vijay, and } \\
\text { Vishal. ICC 10667, ICC 10619, ICC 4935, } \\
\text { ICC 10243, ICCV 95992, and ICC } 10817\end{array}$ & \\
\hline & Leaf miner, Liriomyza cicerina & \multirow{2}{*}{$\begin{array}{l}\text { Singh and Weigand (1994), Girija } \\
\text { et al. (2008) }\end{array}$} \\
\hline & \multirow[t]{2}{*}{ ILC 380, ILC 5901, and ILC 7738} & \\
\hline & & Shankar et al. (2012) \\
\hline & Beet armyworm Spodoptera exigua & \multirow{4}{*}{$\begin{array}{l}\text { Indian Institute of Pulses Research } \\
\text { (2015) }\end{array}$} \\
\hline & ICC 12475 & \\
\hline & Bruchid & \\
\hline & DCP 923, JG 315, BG 1003, BG 372 & \\
\hline & Root-knot nematode & \multirow{2}{*}{$\begin{array}{l}\text { Indian Institute of Pulses Research } \\
\text { (2015) }\end{array}$} \\
\hline & Meloidogyne incognita and M. javanica & \\
\hline \multirow[t]{9}{*}{ Black gram } & Pod borer, Helicoverpa armigera & Lal (1987) \\
\hline & Kalai $^{\mathrm{a}}, 338-3$, Krishna $^{\mathrm{a}}$, and Co $3^{\mathrm{a}}, 4^{\mathrm{a}}$, and $5^{\mathrm{a}}$ & \multirow{3}{*}{$\begin{array}{l}\text { Soundararajan et al. (2010), } \\
\text { Ponnusamy et al. (2014) }\end{array}$} \\
\hline & $\begin{array}{l}\text { CBG 08-011 and PLU 54; UH 82-5, IC } 8219 \\
\text { and SPS } 143\end{array}$ & \\
\hline & Jassid, Empoasca kerri & \\
\hline & Sinkheda $1^{\mathrm{a}}, \mathrm{Krishna}^{\mathrm{a}}, \mathrm{H}$ 70-3, and UPB $1^{\mathrm{a}}$ & \multirow[t]{5}{*}{ Dawoodi et al. (2010) } \\
\hline & Stem fly, Ophiomyia phaseoli & \\
\hline & Killikullam $^{\mathrm{a}}, 338 / 3, \mathrm{P} 58, \mathrm{Co} 4^{\mathrm{a}}$, and Co $5^{\mathrm{a}}$ & \\
\hline & Pink Pod borer Cydia ptychora & \\
\hline & SKNU-03-03 & \\
\hline
\end{tabular}


Table 5.1 (continued)

\begin{tabular}{|c|c|c|}
\hline Crop & Genotypes & References \\
\hline \multirow{8}{*}{$\begin{array}{l}\text { Green } \\
\text { gram }\end{array}$} & Pod borer, Maruca testulalis & \multirow[t]{2}{*}{ Lakshminarayan et al. (2008) } \\
\hline & J1, LM 11, P 526, and P 336 & \\
\hline & ML 337, ML 5, MH 85-61, and ML 325 & \multirow[t]{2}{*}{ Soundararajan et al. (2010) } \\
\hline & CGG 08-007 and CGG 08-028 & \\
\hline & Stem fly, Ophiomyia centrosematis Co 3 & \multirow[t]{2}{*}{ Devasthali and Joshi (1994) } \\
\hline & $\begin{array}{l}\text { TAM-20, PDM-84-143 and Pusa-105 against } \\
\text { A. craccivora, A. kerri (Empoasca kerri) and } \\
\text { M. undecimpustulatus }\end{array}$ & \\
\hline & Bruchids & \multirow[t]{2}{*}{ Somta et al. (2008) } \\
\hline & V1128, V2817 & \\
\hline \multirow[t]{5}{*}{ Field pea } & Pod borer, Etiella zinkenella & Lal (1987) \\
\hline & $\begin{array}{l}\text { EC } 33860, \text { Bonville }{ }^{\mathrm{a}} \text {, T } 6113^{\mathrm{a}} \text {, PS 410, } 2 \mathrm{~S} \\
\text { 21, and } 172 \mathrm{M} \text {. }\end{array}$ & \multirow[t]{4}{*}{ Teshome et al. (2015) } \\
\hline & $32,454,235,002$ & \\
\hline & Leaf miner, Chromatomyia horticola & \\
\hline & $\begin{array}{l}\text { P 402, PS 41-6, T 6113, PS 40, KMPR 9, P } \\
\text { 402, and P } 200\end{array}$ & \\
\hline \multirow[t]{10}{*}{ Cowpea } & Pod borer, Maruca vitrata & Singh (1978), Lal (1987) \\
\hline & $\begin{array}{l}\text { TVu 946, VITA 4, VITA 5, Ife Brown, and } \\
\text { Banswara }^{\text {a }}\end{array}$ & Chanchal and Singh (2014) \\
\hline & $\begin{array}{l}\text { EC 394828, ET 116932, TVNu 946, Kashi } \\
\text { Shyamal, Arka Suman, and Arka }\end{array}$ & \multirow[t]{5}{*}{ Jackai (1981) } \\
\hline & Sumurudhi & \\
\hline & Jassid, Empoasca kerri & \\
\hline & $\begin{array}{l}\text { TVu 123, TVu 662, JG 10-72, C 152, and } \\
\text { 3-779 (1159) }\end{array}$ & \\
\hline & Aphid, Aphis craccivora & \\
\hline & P 1473, P 1476, IT82E-16, and MS 9369 & \multirow[t]{2}{*}{ Benchasri et al. (2007) } \\
\hline & Bruchids Callosobruchus maculatus & \\
\hline & $\begin{array}{l}\text { IT89KD- 288, IT99K-429-2 and } \\
\text { IT97K-356-1 }\end{array}$ & Obadofin (2014) \\
\hline
\end{tabular}

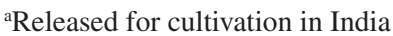

Limited work has been done on insect resistance in lentil crop. Chhabra (1981) reported seven lines showed resistance to pea pod borer E. zinkenella. Chopra and Rajni (1987) ascertained resistance of bruchids, while Sharma and Yadav (1993) accounted resistance to aphid A. craccivora in some of the lentil accessions. Genotypic differences for susceptibility to aphid (A. craccivora), pod borer ( $E$. zinkenella), and seed weevil have been noticed, but no efforts have been made to breed for resistance to these insect pests (Erskine et al. 1994).

The TVNu 946 cultivar showed high levels of resistance to Maruca across seasons and locations (Jackai 1981), and Oghiakh and Odulaja (1993) used the principal component analysis to study the variation patterns in 18 cultivars, 7 developmental 
parameters of the pest on floral buds, flower, and sliced pods against Maruca in cowpea crop. Singh et al. (1996) accounted several improved cowpea varieties with combination of the resistance to aphid, thrips, and bruchid, and Nkansah and Hodgson (1995) confirmed resistance of TVu 801 and TVu 3000 to the Nigerian aphid strain but found that the two lines were susceptible to aphids from the Philippines. IT82E-16 displayed a high level of resistance to cowpea aphid A. craccivora (Benchasri et al. 2007), and the genotypes IT89KD-288(V4) and IT89KD-391 (V2) had the outstanding performance against major insect pests of cowpea in southeastern agroecology of Nigeria (Onyishi et al. 2013). IT89KD- 288, IT99K-429-2, and IT97K-356-1 were resistant to C. maculatus (Obadofin 2014).

In case of green gram (V. radiata) cultivars PDM-84-139 and ML-382 were assuring against Caliothrips indicus, BM-112 for Raphidopalpa sp. (Aulacophora sp.) and PDM-84-143, TAM-20 and Pusa-105 against A. craccivora, A. kerri (Empoasca kerri) and M. undecimpustulatus (Devasthali and Joshi 1994) and MV 1-6 for grasshopper and cotton gray weevil. The cultivar MI-67-9 was resistant against bean aphid but was more susceptible to blue beetle. The sap-sucking jassid infestation was comparatively less in varieties MI-67-3 and MI-29-22 (Devesthali and Saran 1998). Talekar and Lin (1992) ascertained accessions V2709 and V2802 were highly resistant to both $C$. chinensis and $C$. maculatus, while the cultivated accessions V1128 and V2817 were also resistant (Somta et al. 2008) and moderately resistant in PLM 156 and V 1123 for both bruchid species (Dixit 2015). Lower pod borer complex damage was observed in CGG 08-007 and CGG 08-028 (Soundararajan et al. 2010), and resistance in TC1966, V2709, V2802, V1128, and V2817 was attributed due to presence of the biochemical compounds in the seeds (Talekar and Lin 1992; Somta et al. 2008).

The soybean cultivar IAC-100 with having PI 229358 and PI 274454 in its genealogy was formally released in Brazil, and it acquits resistance to stink bug complex (Rosseto 1989). Recently, the pink pod borer, Cydia ptychora (Meyrick), on urdbean/black gram was noticed in some of the regions in Gujarat (Dawoodi et al. 2009), and the variety SKNU-03-03 was showed least susceptible to pink pod borer (Dawoodi et al. 2010). Genotype PLU 648 was found resistant to M. javanica. Low pod borer complex damage was observed in CBG 08-011 and PLU 54 (Soundararajan et al. 2010). In field pea (P. sativum), accessions 32,454 (17\%) and 235,002 (33\%) had consistently low percent seed damage; incorporation of such promising accessions into pea breeding programs may lead to the exploitation of varieties with enhanced resistance against pea weevil, B. pisorum L., in Ethiopia (Teshome et al. 2015). However, lack of precision strategies in evaluating thousands of accessions for resistance to the target insect pests probably resulted in missing many potentially good sources of resistance. Therefore, high-throughput phenotyping has been used in recent times for large-scale evaluation of germplasm or breeding lines for resistance to sap-sucking insects. 


\subsection{Wild Relatives as Sources of Resistance to Insect Pests}

The genes responsible for resistance to insect pests are quite rare in nature for the cultivated species, but they are quite frequent in the wild accessions of many crops. In few cases high levels of resistance in the cultivated germplasm of haricot bean, field pea (Clement et al. 2002), cowpea (Redden et al. 1983), and black gram (Dongre et al. 1996) have been reported. The wild relatives/accessions of pigeon pea and chickpea are authoritative sources of genes for resistance to insect pests. Over the past two decades, the authors ascertained a paradigm shift in identification and deployment of wild species of pigeon pea (Dhillon and Sharma 2012). In case of pigeon pea accessions ICPW 214 (C. bracteata), ICPW 141, ICPW 278, and ICPW 280 (C. scarabaeoides), ICPW 14 and ICPW 202 (F. stricta) have been reported to have resistance to pod fly $M$. obtusa and $T$. cajaninae (Sharma et al. 2003a). In case of C. scarabaeoides (L.) Thouars, C. sericeus (Benth. ex Baker) Maesen and $C$. acutifolius (F. Muell.) Maesen are highly resistant to H. armigera (Green et al. 2006), ICPW 1 (Cajanus acutifolius), ICPW 68 (C. platycarpus), ICPW 13 and 14 (C. albicans), ICPW 159 and 160 (C. sericeus), ICPW 83, 90, 94, 125, 137, 141 and 280 (C. scarabaeoides), ICPW 207 (Paracalyx scariosa) and ICPW 210 (Rhynchosia aurea) showed higher levels of antixenosis/non-preference for oviposition under no-choice, dual-choice and multi-choice conditions against pod borer, H. armigera (Sujana et al. 2008). High levels of antibiosis were found, when the H. armigera larvae reared on leaves and/or pods of C. acutifolius (ICPW 1), C. sericeus (ICPW 160), P. scariosa (ICPW 207), C. cajanifolius (ICPW 29), C. scarabaeoides, and $C$. albicans. The lyophilized leaf or pod powder was incorporated into the artificial diet, which can be used to assess antibiosis to $H$. armigera, and high levels of antibiosis were observed in diets having leaf and/or pod powder of some of the accessions of $C$. acutifolius, C. lineatus, C. scarabaeoides, $C$. sericeus, $C$. platycarpus, $P$. scariosa, and $R$. aurea. The postembryonic development period was prolonged, when insects reared on leaves and pods of wild relatives of pigeon pea. Wild relatives expressing high levels of antixenosis/non-preference and antibiosis can be used to increase the levels and diversify the bases of resistance to $H$. armigera in pigeon pea (Sujana et al. 2008). Efforts have also been made for transfering pod borer resistance from the wild relatives to the cultigens (Jadhav et al. 2012a; Mallikarjuna et al. 2011b). Accessions MA7, TT10, and H845 and accessions of wild relatives ICWP 016 (Cajanus albicans), ICWP 062 (C. platycarpus), ICWP 086, and ICWP 097 (C. scarabaeoides) were identified as resistant to Meloidogyne javanica (Dixit 2015).

Wild relatives/accessions of chickpea species, such as Cicer bijugum C. reticulatumtum., showed high levels of resistance to H. armigera (Sharma et al. 2005c, d), and accessions $C$. pinnatifidum, C. bijugum, and C. echinosper white mum (Davis) showed resistance to bruchid, $C$. chinensis L. (Singh and Ocampo 1998). Chickpea lines received from $C$. reticulatum and $C$. echinospermum were developed and showed for resistance to root lesion nematodes and Phytophthora root rot disease, but these lines are still undergoing backcrossing programs to retrieve the domesticated phenotype lines (T. Knights, personal communication). The recent studies 
(Sandhu et al. 2005; Kaur et al. 2013) showed that $C$. pinnatifi dum, a valuable source for major biotic and abiotic stresses, can be crossed successfully with cultivated chickpea for the deployment of high level of resistance sources to Botrytis gray mold and Ascochyta blight (Kaur et al. 2013).

In lentil, for the first time sources of resistance to Sitona weevil (Sitona crinitus Herbst) obtained from its wild accessions of Lens species, accession ILWL 245 belongs to the species L. culinaris Medikus subsp. orientalis (Boiss.), and a total of 32 accessions including cultivated landraces, $L$. $c$. sp. orientalis, L. nigricans, and L. lamottei showed lower infestation rates than the susceptible check and were selected as potential sources of resistance to seed weevil (Bruchus spp.) (Bouhssini et al. 2008). However, the exploration of 571 accessions from 27 countries including wild species was screened for susceptibility to seed bruchids under unprotected conditions in Central Spain, and the wild species were L. culinaris Medikus subsp. culinaris, L. nigricans (M. Bieb.) Godr., L. culinaris Medikus subsp. orientalis (Boiss.) Ponert, and L. lamottei Cezfr., which showed lower infestation rates of seed bruchids (Bruchus spp.) than the local check "Lyda"(Ruiz et al. 2012). In India, an extensive research on bruchid species infesting lentil was carried out over the past 10 years at National Bureau of Plant Genetic Resources, New Delhi (Bhalla et al. 2004).

In soybean, wild relative PI 171444 (MG VI) was found to be the majorly resistant and exhibited antixenosis, antibiosis, and temporal separation (Kester et al. 1984), and the lines PI 229358, PI 227687, and PI 274454 expressed antixenosistype resistance against Anticarsia gemmatalis (Hubner) (Lepidoptera: Noctuidae) (Hoffmann-Campo et al. 2006; Ortega et al. 2016) PI 227687 also provoked repellency to Trichoplusia ni caterpillars and adults of Epilachna varivestis, verified for the presence of volatile derivatives of their leaves (Liu et al. 1989). PI 567336A and PI 567598B were confirmed as the most resistant wild relatives and were characterized as having antibiosis resistance to kudzu bug (KZB), Megacopta punctatissima Montandon (Bray et al. 2016). For soybean cyst nematode, resistance source has been effectively exchanged from its wild-lasting soybean, Glycine tomentella Hayata (Riggs et al. 1998); however, its cultivars are still in an exploratory stage.

Recently, a draft genome sequence of mung bean was described (Kang et al. 2014), and sequence is useful for gene identification and development of DNA markers for specific trait(s) of interest in breeding program. Till date, various sources of resistance against bruchids have been identified in mung bean crop. Fujii and Miyazaki (1987) depicted first report on wild relatives of mung bean (V. radiata var. sublobata) and the accession TC1966 and ACC23 and ACC41 (Lambrides and Imrie 2000) and recently identified accession Sub2 in Vigna radiata var. sublobata for resistance to both bruchid species (Sarkar and Bhattacharyya 2015). The Phaseolus wild relatives are as of now by and by being screened for resistances to bruchids and other seed storage insect pests (Singh 2001, J. Beaver, individual correspondence, S. Beebe, individual correspondence, D. Debouck, individual correspondence). In case of wild relative of pea, Pisum fulvum (Sibth. \& Sm.) is resistant to the bruchid, Brichus pisorum L. (Clement et al. 2002), while the wild relative of cowpea, Vigna 
vexillata (L.) Benth, is resistant to pod-sucking bug, Clavigralla tomentosicollis Stal, and spotted pod borer, M. vitrata (Jackai and Oghiakhe 1989).

\subsection{Mechanisms of Resistance to Insect Pests}

Maxwell and Jennings (1980) defined insect resistance as "those heritable characteristics obsessed by the plant which regulate the ultimate degree of damage done by insects". Crop plants have developed various mechanisms of resistance, which have been classified as non-preference or antixenosis for oviposition and feeding; antibiosis showed in terms of reduced survival, prolonged development, and reduced fecundity; and recovery or tolerance to insect damage in terms of ability to withstand insect damage or production of additional branches, tillers of another flush of flowering, and fruiting bodies. All these mechanisms of resistance have been observed against different insects in various legume crops (Schoonhoven et al. 2005; Sharma et al. 2011).

\subsubsection{Oviposition Non-preference or Antixenosis}

Cowgill and Lateef (1996) and Sison et al. (1996) commemorated fewer eggs on the resistant/tolerant genotype ICC 506 EB than on ICC 4918 and ICCC 37. Comparatively lower egg laying was also recorded in hybrids based on ICC 12477, ICC 12478, ICC 12479, and ICC 506 EB as compared to the hybrids based on the susceptible check, ICCC 37, indicating that egg laying on $\mathrm{F}_{1}$ hybrids is influenced by the parents and is inherited in the progeny (Narayanamma et al. 2007), and there is a positive correlation among numbers of eggs laid under laboratory and field conditions (Srivastava and Srivastava 1989). Antixenosis and antibiosis types of resistance have been ascertained against $C$. chinensis $\mathrm{L}$. in chickpea and faba bean (Clement et al. 1994).

In case of pigeon pea, oviposition for non-preference was shown in ICPL 187-1, ICP 7203-1, ICPL 84060, ICPL 88039, T 21, and ICPL 332 under no-choice, dualchoice, and multi-choice conditions (Kumari et al. 2006). Wild Cajanus accessions (C. acutifolius and C. sericeus) were having extravagantly levels of antixenosis for oviposition of $H$. armigera (Sharma et al. 2009). Bean cultivars IAC-Harmonia, IAPAR-81, IPR-Eldorado, and IPR-Siriri were the less preferred for oviposition; and the IAC-Harmonia stretched the whitefly B. tabaci life cycle, expressing nonpreference for feeding and/or antibiosis-type resistance (Silva et al. 2014). Cowpea variety TVNu 946 exhibits non-preference to M. testulalis for oviposition/egg laying when compared to Ife Brown and VITA 1 cultivars (Macfoy et al. 1983); there is no ovipositional antixenosis in some of cowpea cultivars to the pod borer by Valdez (1989). Trichomes on the pods of $V$. vaxillata, a wild relative of cowpea, are partially responsible for resistance to C. tomentosicollis Stal. (Chiang and Singh 1988). Singh (2002a, b) suggested that varieties with pigmented calyx, petioles, pods, and pod tips suffered least damage from legume spotted pod borer M. vitrata. 
Durairaj et al. (2009) ascertained most of the wild relatives were found susceptible to aphids and other sucking insect pests, and both antixenosis and antibiotic type of resistance have been observed against E. fabae, E. varivestis, and B. pisorum L. (Clement et al. 1994). The pea varieties having yellow-green color are less preferred to the pea aphids than the blue-green ones (Painter 1951), and varieties deficient in certain amino acids are also shown to be resistant to the pea aphid A. pisum (Harris). In soybean varieties without pubescence were extensively damaged by the potato hopper, while those with pubescence seemed to be unaffected (Fehr 1987), and nonpreference for oviposition is one of the major components in $H$. zea resistance in PI 2227687 soybean (Horber 1978).

\subsubsection{Antibiosis}

This mechanism of resistance is typically associated with plant biochemical parameters, like the presence of free amino acids, fatty acids, and fibers in the leaflets, which may have adverse effects on an insect that attempts to colonize it, affecting the biological performance of the insect (Panda and Khush 1995; Smith 2005). Antibiosis is a component of resistance to H. armigera in pigeon pea and chickpea, which is showed in terms of reduced larval survival, fecundity, and weight gain and prolonged larval development (Kumari et al. 2010b). Reduced larval and pupal weights and prolonged larval and pupal developmental periods were observed in insects reared on entire leaves or pods of ICPL 332, ICPL 84060, ICPL 88039, ICP 7035, and T 21. Similar effects were observed when larvae reared on artificial diet impregnated with lyophilized leaves or pods of aforesaid cultivars (Kumari et al. 2010a). Wild Cajanus accessions have high manifestations of antibiosis (C. acutifolius (Benth. ex Baker) Maesen) against pod borer (Sharma et al. 2009).

Antibiosis showed in terms of decreased larval, larval mortality, and pupal weights, extended larval and pupal periods, failure to pupate, and reduced fecundity, and egg viability contributed to antibiosis of resistance to $H$. armigera in chickpea (Srivastava and Srivastava 1989; Yoshida et al. 1995; Cowgill and Lateef 1996; Narayanamma et al. 2007). Larval survival and larval weight were lower on ICC 506 EB, ICC 12476, ICC 12477, and ICC 12478 when contrasted with that on ICCC 37. In addition, the isoflavonoids can interfere negatively with insect feeding, oviposition, and development (Harborne and Williams 2000; Simmonds 2003). The bean genotype IAC Una and Raz 49 were classified as highly susceptible and highly resistant, respectively, by Costa et al. (2013).

The cowpea cultivar MNC 99-541 F21 showed antibiosis against the whitefly $B$. tabaci biotype B, extending the life cycle of the insect, and genotypes Canapu, BRS-Urubuquara, and TE97-304 G-4 also showed antibiosis, causing high nymphal mortality (Cruz et al. 2014); Koona et al. (2002) accounted that TVnu 151 exhibited antibiosis for C.tomentosicollis, causing high nymphal mortality, and the larval survival of $M$. vitrata was low on cowpea variety TVNu 946, and it was due to the antibiotic and nutritional factors (Macfoy et al. 1983; Saxena 1989). Valdez (1989) observed only a slight effect of the host on larval survival, and Okech and Saxena 
(1990) indicated that stem and pods act as antibiosis component of resistance in TVNu 946 and VITA 5. In general, antibiosis consequences are expressed in terms of weight and size of insects, sex ratio, and proportion of insects entering diapause (Basandrai et al. 2011). Four green gram accessions LM 131, V 1123, LM 371, and STY 2633 and three black gram accessions UH 82-5, IC 8219, and SPS 143 were found to be moderately resistant to bruchid $C$. chinensis having less percentage survival and prolonged developmental period as compared to susceptible check (Ponnusamy et al. 2014).

\subsubsection{Tolerance}

Ability to withstand insect damage that results in lower loss of grain yield indicates the ability of different genotypes to recover from insect damage. However, tolerance is more subject to variation because of environmental conditions than non-preference and antibiosis. The age or size and general vigor of the plant and size of the insectresistant population also strongly influence the degree of tolerance.

Reduction in grain yield also renders a good measure of agronomic performance and the genotypic ability to withstand $H$. armigera damage. If there should arise an occurrence of chickpea, plant recuperation from harm recuperation by $H$. armigera was better if there should be an occurrence of ICC 506 EB, ICC 12476, and ICC 12479 when contrasted with the vulnerable check, ICCC 37 (Narayanamma et al. 2007). The misfortune in grain yield was lesser in the event of ICCV 2, ICC 12478, ICC 12479, and ICC 506 EB crosswise over crop phenology stages and pervasion technique conventions when contrasted with that on the vulnerable check, ICCC 37. Pigeon pea ICPL 187-1, ICPL 98008, ICP 7203-1, T 21, ICP 7035, and ICPL 332 showed moderate levels of resistance to $H$. armigera across planting dates. ICPL 187-1, ICPL 84060, ICP 7203-1, ICPL 87119, and ICPL 332 suffered lower loss in grain yield than the susceptible checks, ICPL 87 and ICPL 87091, under unprotected conditions (Kumari et al. 2010b).

\subsection{Morphological and Biochemical Traits Associated with Insect Resistance}

\subsubsection{Phenological Traits}

Pigeon pea genotypes having determinate growth habit, clustered pods, and dense plant canopy are more prone to be susceptible to pod borers, H. armigera and $M$. vitrata, than genotypes with non-clustered pods (Sharma et al. 1997), while the genotypes with smaller pods, pod wall thick and tightly fitting to the seeds, and a deep constriction between the seeds are less susceptible to H. armigera (Nanda et al. 1996). The varied plant growth types and maturity also influence genotypic susceptibility to pod fly, M. obtusa, but podwall thickness, trichome density, and amount crude fiber content are associated with resistance to H.armigera in pigeon 
pea (Moudgal et al. 2008). Sharma et al. (2009) observed higher density of type "C" and "D" trichomes present in wild relatives of C. scarabaeoides and C. sericeus, and there are 5-6 traits that distinguish $C$. cajanifolius from pigeon pea such as flower morphology, pod color, morphology, pod constriction, seed color, and 100 seed weight (Mallikarjuna et al. 2012).

Pod wall thickness, plant growth habit, and crop duration influence pod borer $H$. armigera damage in chickpea (Ujagir and Khare 1988). Pubescence on the leaf tip is linked with reduced defoliation by H. zea (Boddie), S. exigua (Hubner), and Pseudoplusia includens (Walker) in soybean (Hulburt et al. 2004). The length of the peduncle and angle of pods influence expression of resistance to $M$. vitrata in cowpea (Soundararajan et al. 2013). Oghiakhe et al. (1991) reported that defoliated cultivars suffered lower damage than the undefoliated ones, and the cultivars $\mathrm{TVu}$ 946 and TVu 4557 having attributes of high length of the peduncle and angle of pods (Singh 1978) erect and profuse flowering in TVu 946 (Oghiakhe et al. 1992a, b) for resistance $M$. vitrata in cowpea. The bunched pods suffered greater damage by legume pod borer (Usua and Singh 1979). Pubescence in wild and cultivated cowpea $V$. vexillata and $V$. unguiculata badly affected oviposition, mobility, and food consumption by the legume pod borer in tests conducted with TVNu 729 (wild, highly resistant and highly pubescent), TVNu 946 (semi wild, moderately), and IT 82D-716 (cultivated, highly susceptible, and pubescent) (Oghiakhe 1995).

In green gram, fewer number of bruchid eggs were recorded on small and shiny seeds as compared to large and dull seeds, and in black gram, small and black seeds recorded lesser number of eggs as compared to large and green seeds (Ponnusamy et al. 2014); and the neoplasm formation, thicknesses of podwall, and micromorphological traits attributed for a reduced oviposition rate of female pea weevil on genotype 235,899-1 (Mendesil et al. 2016). In Dolichus bean, the foliage color, days to $50 \%$ flowering, flower color, pod color, pod texture, and fragrance influenced genotypic susceptibility to $M$. vitrata (Mallikarjuna et al. 2009).

\subsubsection{Leaf Hairs and Trichomes}

Leaf hairs (that do not produce glandular secretions) play a pivotal role in host plant resistance to insects. Wild relatives of pigeon pea such as Cajanus scarabaeoides and $C$. acutifolius with nonglandular trichomes are not preferred by $H$. armigera females for egg laying (Sharma et al. 2001a; Sujana et al. 2012). Trichomes (hairlike outgrowths on the epidermis of plants that produce glandular secretions) also play an important role in host plant resistance to insects. Hooked trichomes in bean vitiate the movement of the aphid, A. craccivora (Johnson 1953), and potato leafhopper, E. fabae (Pillemer and Tingey 1978). Glandular trichomes in pigeon pea are linked to H. armigera susceptibility (Peter et al. 1995; Sharma et al. 2001a; Green et al. 2003; Sujana et al. 2012).

Trichomes and their organic exudates in chickpea also influence the movement and feeding behavior of neonate larvae of $H$. armigera (Stevenson et al. 2005) and influence the feeding of spotted pod borer larvae, M. vitrata, in cowpea (Jackai and 
Oghiakhe 1989) and cabbage looper, Trichoplusia ni (Hubner), in soybean (Khan et al. 1986). Trichomes on a wild relative of cowpea (Vigna vexillata) pods are partly responsible for resistance to the pod-sucking bug, Clavigralla tomentosicollis Stal. (Chiang and Singh 1988). The density and length of trichomes are linked with resistance to pod borers in short-duration pigeon pea, while trichome density on upper and lower surface parts of the leaf (390 and 452/9 $\mathrm{mm}^{2}$ ), trichome length $(3.5 \mathrm{~mm})$, and trichome density $\left(442.9 \mathrm{~mm}^{2}\right)$ and length $(5.9 \mathrm{~mm})$ on pods are positively correlated with the resistance to pod borer, H. armigera (Sunitha et al. 2008a).

Potential effects of trichomes on whiteflies may vary depending on trichome angle to the leaf surface, length and type, all factors potentially affecting adult oviposition, and immature attachment and feeding in black gram (Channarayappa et al. 1992), and the genotypes having shorter trichomes are inclined to resistance against B. tabaci. Another fact revealed that the black gram genotypes possessing erect trichomes were resistant to $B$. tabaci, and thus greater erectness of foliar trichomes seemed to disturb and retard the settling and probing (for oviposition and feeding) behavior of the whitefly in resistant genotypes of black gram (Lakshminarayan et al. 2008; Taggar and Gill 2012).

\subsection{Biochemical Mechanisms of Resistance}

\subsubsection{Nutritional Factors}

Nutritional parameters, viz., sugars, phenols, proteins, fats, sterols, and essential amino acids and vitamins, also influence on host plant suitability to insect pests. Total soluble sugars present in pigeon pea pod wall, which influence the pod damage by $H$. armigera. Apart from sugars, the protein content of the pod wall is also associated with susceptibility, while total sugars are associated with resistance to $M$. obtusa in pigeon pea (Moudgal et al. 2008). Higher sugar content present in flower $(22 \%)$ and pods $(10.6 \%)$ was responsible for the susceptibility of ICPL 88034, while higher phenol concentration in flowers $(6.5 \%)$ and pods $(9.3 \%)$ in ICPL 98003 was responsible for resistance. Protein percent in pods was significantly higher $(25.5 \%)$ in susceptible ICPL 88034 when compared with resistant ICPL 98003 (16.5\%) (Sunitha et al. 2008b).

Pea varieties deficient in certain amino acids, which influence for resistant to the pea aphid, A. pisum (Auclair 1963). Higher amounts of nonreducing sugars and lower amounts of starch in chickpea variety GL 645 attribute for its low susceptibility to H. armigera (Chhabra et al. 1990). Mung bean varieties with high sugar and amino acid content in leaves are resistant to whitefly, B. tabaci, and the jassid, Empoasca kerri (Ruth) (Chhabra et al. 1988). Soybean-resistant genotypes possessed high amount of fats, protein, and anti-nutritional factor (phenol and four to five times more trypisn inhibitors) than cowpea and chickpea (kabuli> desi) genotypes which contain high amount of carbohydrates and low amount of anti-nutrional factors and were susceptible toward Callosobruchus species (Sharma and Thakur 2014). 
Nonprotein or unusual amino acids afford protection against herbivores in several plant species. The protective effect is elicited via their structural analogy to the most commonly occurring essential amino acids. Among these, L-canavanine, 2, 4-diamino butyric acid, azetidine-2-carboxylic acid, minosine, and 3-hydoxyproline have substantial growth inhibition effects on insects (Parmar and Walia 2001). L-canavanine is a structural homologue of L-arginine and takes place in over 1500 leguminous plant species. Some of the nonprotein amino acids also act as enzyme inhibitors; canaline - a hydrolytic product of canavanine - inhibits pyridoxal phosphate-dependent enzymes by forming a covalent bond (Ishaaya et al. 1991). Black gram cultivars NDU 5-7 and KU 99-20 registered higher peroxidase and catalase activities at 30 and 50 DAS under whitefly-stress conditions as compared with non-stressed plants (Taggar et al. 2012).

\subsubsection{Secondary Metabolites}

Plants also produce various defensive secondary metabolites in reaction to biotic and abiotic stresses. The secondary metabolites do not involve in the normal growth and development of plant but reduce its palatability of the plant tissues to the herbivores (Boerjan et al. 2003). Some of the secondary metabolites also influence in host finding, oviposition, feeding, and survival and growth and development of insects and play a major role in host plant resistance to insects in grain legumes. Among the secondary metabolites, plant phenols constitute one of the most common and widespread groups of defensive compounds, which play a pivotal role in host plant resistance against herbivores, including insects (Sharma et al. 2009; Usha Rani and Jyothsna 2010; Ballhorn et al. 2011). Qualitative and quantitative alterations in secondary metabolites and increase in activities of oxidative enzymes in plants in response to herbivore attack are a common mechanism of resistance to insects (War et al. 2013). Quercetin, quercitrin, and quercetin-3-methyl ether in the pod surface exudates of pigeon pea play a major role in host plant selection by $H$. armigera larvae in pigeon pea (Green et al. 2002, 2003). Stilbene, a phytoalexin, occurs at high concentrations in pigeon pea cultivars with resistance to $H$. armigera (Green et al. 2003). Total phenols and tannins present in the pod wall of pigeon pea are negatively associated with pod fly damage (Moudgal et al. 2008).

Protease inhibitors are another major class of anti-nutrional factors in chickpea and pigenopea, which have shown $H$. armigera microbial gut protease inhibitory activity in developing seeds of wild and cultivated chickpea (Parade et al. 2012). Amylase and protease inhibitors in pigeon pea showed to have an adverse effect on growth and development of $H$. armigera (Giri and Kachole 1998). There is appreciable variation in $H$. armigera gut protease inhibitory activity in developing seeds of chickpea (Patankar et al. 1999), and proteinase inhibitors from the nonhost plants (groundnut, winged bean, and potato) are more efficient in inhibiting the gut proteinases of $H$. armigera larvae than those from its favored host plants such as chickpea, pigeon pea, and cotton (Harsulkar et al. 1999). Amounts of trypsin inhibitor (TI) in desi chickpea cultivars ranged between 17 and $31 \mathrm{mg} / \mathrm{g}$ of sample. The TI 
activity was greater in P-256 (39.47 $\pm 1.91 \mathrm{TUI} / \mathrm{mg})$ than in Pusa Pragati $(6.19 \pm 0.56$ TUI/mg) (Kansal et al. 2008). The wild relatives of pigeon pea belonging to $C$. albicans, C. cajanifolius, C. sericeus, Flemingia bracteata, and Rhynchosia bracteata showed high levels of resistance to $H$. armigera and exhibit high levels of protease inhibitors $(P I s)$ activity under in vivo and in vitro against $H$. armigera gut proteinases (HaGPs) (Parade et al. 2012). Sterols and soybean leaf extract in combination with sucrose act as phagostimulant to the larvae of the cabbage looper, Trichoplusia ni (Hub.) (Sharma and Norris 1994a). Higher acidity in the leaf exudates of chickpea is linked with resistance to H. armigera (Srivastava and Srivastava 1989). The polar solvent extractable of the soybean genotype PI 227687 resistant to the cabbage looper, $T$. ni, contains daidzein, coumestrol, sojagol, and glyceollins. These compounds reduce feeding, survival, and growth and development of the cabbage looper, T. ni (Sharma and Norris 1991, 1994b). In soybean, pinitol confers resistance to $H$. zea (Boddie) (Dougherty 1976).

Malic acid in chickpea leaf organic acid exudates acts as an antifeedant and less palatable to the $H$. armigera larvae (Bhagwat et al. 1995). Oxalic acid exudates inhibit the growth and development of $H$. armigera larvae when incorporated into synthetic diet, while malic acid shows no growth inhibition on H. armigera (Yoshida et al. 1995, 1997). The chickpea having flavonoids judaicin 7-O-glucoside, 2-methoxy-judaicin, judaicin, and maakiain present in wild relatives of chickpea (Cicer bijugum and $C$. judaicum) have shown an antifeedant activity for the larvae of $H$. armigera (Simmonds and Stevenson 2001). In common bean genotypes, arcelin protein and trypsin inhibitors are the major secondary metabolites for resistance to bean weevil Zabrotes subfasciatus (Blair et al. 2010).

\subsection{Inheritance of Resistance to Insects in Grain Legumes}

Greater magnitude of $\sigma^{2} \mathrm{~A}$ (17.39) than $\sigma^{2} \mathrm{D}$ (3.93) clearly showed preponderance of $\sigma^{2} \mathrm{~A}$ in the inheritance of legume pod borer, H. armigera resistance (Narayanamma et al. 2013a). Gowda et al. (2005) ascertained that additive and dominance genetic variances were majorly predominant in early and medium maturity diallel trials, respectively. Additive as well as dominance components of genetic variances were equally important in the inheritance of legume pod borer $H$. armigera resistance in late maturity group. Such derivative nature of gene action controlling pod borer resistance in varied maturity groups has earlier been reported by Gowda et al. (1983) and Singh et al. (1991). Salimath et al. (2003) accounted in the involvement for both additive and nonadditive gene action in the inheritance of pod borer resistance, although their results were maturity non-specific. Cotter and Edwards (2006) reported that heritability of larval execution was maximum for neonates than for third-instar larvae in noctuid moth, $H$. armigera, on a resistant and a susceptible variety of the chickpea, $C$. arietinum. There was absence of genetic correlation between larval performance and oviposition preference, showing that female moths do not select the most suitable plant for their offspring. 
Combining ability studies showed the preponderance of nonadditive type of gene action for resistance to $H$. armigera and $M$. vitrata in pigeon pea (Lal 1987). Verulkar et al. (1997) suggested the involvement of a single dominant gene in antixenosis mechanism of resistance in C. scarabaeoides to H. armigera and M. obtusa. Nonglandular trichomes, which are linked with resistance to $H$. armigera in $C$. scarabaeoides, are inherited as a predominant trait (Rupakala et al. 2005). The $H$. armigera-resistant parents, viz., ICC 506 EB, ICC 12478, ICC 12477, ICC 12479, and ICCV 2, proved to be the best general combiners for pod borer resistance with significantly negative gca effects and low pod borer damage (Narayanamma Lakshmi 2005; Sreelatha et al. 2008; Narayanamma et al. 2013b). The hybrids ICC $506 \times$ ICC 3137, ICC $12477 \times$ ICC 4918, ICC $12476 \times$ ICC 3137 , ICC $12479 \times$ ICC 3137, and ICC $3137 \times$ ICCV 2 showing significant and negative sca effects were having good specific combiners for resistance to pod borer damage done by $H$. armigera. Although there is a good balance between pod borer damage of crosses and their sca effects, the crosses (involving parents with contrasting gca effects) with significant sca effects need to be overworked for developing varieties on pod borer resistance and high grain yield parameters. Singh et al. (1997) could create pod borer-resistant chickpea line, ICCV 7, utilizing pedigree selection of the lines gotten from a combination of $\mathrm{H} 208$ and BEG 482. Further, that the loci of pod borer resistant are different in different resistant sources (Dua et al. 2005), pyramiding of genes from different resistant sources will be effective in increasing the levels of pod borer resistance in chickpea. The identification and evaluation of breeding lines which have dual resistance to pod borer and Fusarium wilt, which help in IPM program (Singh et al. 1990; Lateef 1990; Lateef and Sachan 1990; Van Rheenen 1992; Chaturvedi et al. 1998; Sharma et al. 2003b), are important for increasing productivity of chickpea. Recently identified germplasm line (IPC 96-3 and FG 1235) having dual resistance to pod borer and Fusarium wilt (Harminder et al. 2005) could be used as potential donor source to develop chickpea varieties for sustainable crop production.

On the basis of specific combining ability estimates, the cross JAKI$9218 \times$ AKG-10-1 was found to be the best specific combination for seed yield, larval count, malic acid content, and percent of pod borer damage when compared to cross ICCV-2×Chandrapur Chanoli and JAKI-9218×Bushy Mutant (Jadhav and Vijaykumar 2015). The ratio of sca/gca was greater than one for seed yield per plant, larval count at vegetative and pod formation stages, and percentage of pod damage, thereby signifying the preponderance of nonadditive variance in the expression of these characters, whereas additive variance was found to be predominant in the expression of larval count at flowering stage and in malic acid content (Jadhav and Vijaykumar 2015). The identification of various breeding lines, viz., ICCL 87317, ICCL 87316, and ICCV 95992 having stable resistance to H. armigera and high grain yield potential, and germplasm lines, viz., ICC 12478, ICC 14876, and ICC 12479 having stable resistance to pod borer $H$. armigera and moderate yield potential (Sreelatha et al. 2003), could be used in heighten for pod borer resistance in elite agronomic traits. Similar results were reported by Singh and Singh (1990) in pigeon pea for pod fly resistance. 
Since gca effects are the demonstration of additive properties of genes, parents selected based on gca effects will be useful for arising breeding lines with higher grain yield (Narayanamma et al. 2013b) and desirable levels of the trait of interest. Based on gca effects, the genotypes ICC-506 and ICCV-2 have good genetic potential for their utilization in further breeding programs for genetic improvement of pod borer H.armigera resistance in chickpea by using them as one of the parents in hybridization and isolating desirable segregants for resistance to pod borer. Most promisingly, the parent ICC-506 can be extensively used in the hybridization program to accelerate the pace of genetic improvement for pod borer resistance in chickpea. In lentil, ILWL 245 line is being used to transfer introgress resistance genes to cultivated and study the inheritance of Sitona weevil resistance in lentil (Bouhssini et al. 2008). Pathak (1988) studied the genetic resistance of cowpea aphid and reported a single dominant gene, designated as Racl and Rac2. Ombakho et al. (1987) also studied in F1 and F2 generation of cowpea (TVU 310, ICV10, and ICV 11) and reported that resistant gene in TVU 310 and ICV 10 was designated by Acl, while resistant gene in ICV11 was Ac2.

\subsection{Wide Hybridization}

Transferring gene from wild relative species to the cultivated species to confer an adaptive resistance to $H$. armigera is one of the potential options for crop improvement. Wild Cajanus species are the reservoir of many important trait-specific genes and can be utilized to improve the crop cultivars, enrich variability and diversity, and broaden the genetic base and the pre-breeding populations involving wild Cajanus species from its secondary gene pools (C. cajanifolius (ICPW 29), C. scarabaeoides (ICPW 281), C. sericeus (ICPW 159 and 160), C. reticulatus, C. acutifolius (ICPW12 and ICPW 004), C. albicans (ICPW 14)) and tertiary gene pools ( $C$. platycarpus (ICPW 68), Rhynchosia aurea, and R. bracteata)) as donors for traitspecific genes and pigeon pea cultivars as recipients, while these crosses are being further advanced to develop introgression lines (ILs) with high levels of resistance to pod borer (Sharma and Upadhyaya 2016). The wild Cicer species such as $C$. reticulatum, C. pinnatifidium, and C. echinospermum showing high levels of resistance to $H$. armigera can be used in wide hybridization in crop improvement program (Sharma et al. 2005a, 2006). The cross-incompatibility among cultivated chickpea and its tertiary gene pool are post-zygotic (Mallikarjuna 2001; Babb and Muehlbauer 2005), and hence, there is a need to formulate bridge cross between tertiary and secondary gene pool and then use the progeny in further crosses with the cultigen. Recently introgression studies have been done on pod borer (H. armigera), pod fly, bruchid resistance, and other agronomic traits in pigeon pea for opting improved cultivar for sustainable crop production (Mallikarjuna et al. 2011a), and also advanced generation population from the cross-utilizing $C$. acutifolius as the pollen parent has shown resistance for pod borer damage (Mallikarjuna et al. 2007; Jadhav et al. 2012a), for opting variation for seed color and high seed weight. Some of the lines showed high level of resistance to pod borers and pod fly under 
natural field conditions and for bruchid resistance studies for cultivated pigeon pea under storage conditions (Jadhav et al. 2012b).

There is lack of an authentic information of resistance to pea weevil in cultivated $P$. sativum accessions led to the geographical expedition and identification of resistant sources from its secondary gene pool of Pisum, which ensured in the breakthrough of pod and seed resistance in P. fulvum accessions (Clement et al. 2002). The $P$. fulvum accession ATC113 (PI 595933) was successfully crossed with $P$. sativum accession Pennant, and it produced interspecific progenies with having resistant traits in lines (Byrne et al. 2008), and the development of introgression line for pea weevil resistance into cultivated field pea was further confirmed by using advanced backcross lines of the original population (Aryamanesh et al. 2012). Development of first QTL markers is developed by interspecific hybridization among cultivated field pea and P. fulvum (resistance source) against pea weevil and identified three QTL regions associated resistance in cotyledon (linkage groups LG2, LG4, and LG5), pod wall/seed coat (linkage groups LG2 and LG5), and pod wall (on LG7) (Aryamanesh et al. 2014). Recently, Pandiyan et al. (2010) described a number of cross-sectional and cross- subgenus hybrids; amid these hybrids, the cross between $V$. radiata and $V$. umbellata is especially shown significant as $V$. umbellata possesses with a high level of resistance to bruchid beetles, one of the most serious and concern pests of Vigna.

\subsection{Marker-Assisted Selection}

As we know, pod borer (H. armigera) is perhaps the major threat to chickpea and pigeon pea in terms of production and productivity. Screening has been done over 5000 germplasm accessions divulged that still there is no resistant strain or source against this insect pest (Kumar et al. 2004). While few resistance sources were identified in the past in cultivated gene pool, they showed either inconsistency or low levels of resistance lending to their little development in breeding programs (Lateef 1990). Therefore, there is urgency to identify stable sources of genetic resistance in the crossable gene pool for pod borers to facilitate conventional genetic crop improvement programs. The use of undiscovered genes in existing gene pools and the utilization of wild relatives as a rich reservoir of resistance genes against both abiotic and biotic stresses should be given special attention to broaden the genetic base of breeding pool (Clement et al. 2009). In recent days, the development of newer molecular markers and other genomic sources has been quickened in major chickpea, pigeon pea, and some other pulse crops, and marker-assisted trait associations have been established for a number of important agronomic traits (Kumar et al. 2011). The wide pertinency of marker-assisted selection (MAS) has already been demonstrated in cowpea and pea crop, while in the case of lentil and faba bean, it is in infancy stage. The recent approach for the development resistance trait for major legume crops by deploying genomics-assisted breeding (GAB) holds promise in enhancing the genetic gains and discovery of genome-wide genetic markers, highthroughput genotyping/high-throughput phenotyping and sequencing platforms, 
and high-density genetic linkage/QTL maps, and, more importantly, the availability of whole-genome sequence helps in speeding up the progress of genetic improvement of major pulses, which lead to rapid development of cultivars with higher yield, enhanced stress tolerance, and wider adaptability (Bhora et al. 2014).

Progress in marker-aided selection for development of resistance to insect pests in grain legumes though limited extent has been discussed by Sharma et al. (2008). Mapping the complex traits like resistance to pod borer, H. armigera, in chickpea is the only that just started (Lawlor et al. 1998). A cross between a wilt-resistant kabuli variety (ICCV 2) and a wilt-susceptible desi variety (JG 62) has been used to develop the first intraspecific genetic linkage map of chickpea using mapping population (Cho et al. 2002). This population has been further evaluated for resistance to pod borer $H$. armigera, and the data analysis is under progress. An interspecific population derived from ICC 4958 (C. arietinum) x PI 489777 (C. reticulatum) has been evaluated for opting resistance to beet armyworm, S. exigua (Hub.) (Clements et al. 2008), and pod borer, H. armigera (Sharma, H.C., Unpublished), and this population is being genotyped for identification of markers for resistance to these insects. Similarly another mapping population between Vijay and ICC 506EB has also been developed and evaluated for $\mathrm{H}$. armigera, and in pigeon pea, also a mapping population between $C$. cajan and $C$. scarabaeoides is under development at ICRISAT (Upadhyaya HD, personal communication).

However, genetic improvement program has always been impeded with limited genetic variability under primary gene pool of pigeon pea, and its wild species present in the secondary and tertiary gene pools have been reported to carry forward resistance against major insect pests. However, till date deployment of resistance genes through conventional backcrossing has not been much successful. So now it especially calls for development of gene introgression through marker-assisted backcrossing (MABC) or advanced backcross breeding ( $\mathrm{AB}$ breeding) for the development of improved insect pest-resistant cultivars (Choudhary et al. 2013). A cross among an aphid (A. craccivora)-resistant cultivated cowpea (IT 84S-2246-4) and susceptible wild cowpea (NI 963) has also been evaluated for aphid screening resistance and RFLP (restricted fragment length polymorphism) marker segregation (Myers et al. 1996). The RFLP marker bg4D9b was connected to the aphid resistance gene (Rac1), and furthermore, a few flanking markers in a similar linkage gathering (linkage bunch 1) have additionally been identified and described. Taran et al. (2002) identified the genetic linkage map of common bean. The genetic loci for resistance to potato leafhopper, Empoasca fabae (Harris), were detected by Murray et al. (2004). In green gram, TC1966 bruchid resistance gene has been mapped by adopting RFLP markers (Young et al. 1992). Resistance was mapped to a single locus on linkage group VIII (approximately $3.6 \mathrm{cM}$ from the nearest RFLP marker), and based on RFLP analysis, a progeny was also identified in the $\mathrm{F}_{2}$ population that maintained the bruchid resistance gene among a tightly linked double crossover. This progeny would be useful for developing bruchid-resistant mung bean lines and free of linkage drag. For introgression of the bruchid resistance gene in green gram, Yang et al. (1998) used RFLP marker-assisted selection in backcross breeding, while Kaga and Ishimoto (1998) studied genetic determination of a 
bruchid resistance gene and its relationship to insecticidal cyclopeptide alkaloids, the vignatic acids in green gram. Villareal et al. (1998) reported random amplified polymorphic DNA (RAPD) markers have also been used to identify markers linked to the bruchid resistance in mung bean. The $\mathrm{Br}$ locus confirms a bruchid resistance in mung bean, $\operatorname{VrPGIP} 2$ (encoding a polygalacturonase inhibitor) is a strong candidate gene for resistance, and $\operatorname{VrPGIP} 2$ sequence genes were varied between resistant and susceptible lines (Chotechung et al. 2016). The gene was $25 \mathrm{cM}$ from pM151a. Whenever pM151a and pM151b were conceived considered as alleles of a similar locus, the bruchid resistance genes were found $11.9 \mathrm{cM}$ from its closest RAPD marker Q04 sub 900 and $5.6 \mathrm{cM}$ from pM151. The progress has been made for the crosses between field pea ( $P$. sativum) and the wild species (P. fulvum) to locate molecular marker resistance gene to pea weevil in (Byrne et al. 2002). There have been no definitive efforts that has been made to identify QTLs associated with insect resistance in pigeon pea (Sharma 2009), but mapping population based on $C$. cajan x C. scarabaeoides has been developed and is under evaluation stage for resistance to $H$. armigera to identify QTLs linked for resistance to pod borer in pigeon pea.

To date, the sources of cowpea aphid (CPA) resistance and major quantitative trait loci (QTL) reported only for peanut crop (Herselman et al. 2004) and M. truncatula (Kamphuis et al. 2012). Genetic mapping for CPA resistance in cowpea would facilitate for identifying syntenic areas in other legumes, as they may confabulate similar physiological responses against CPA infestation (Kamphuis et al. 2013). Development of African cowpea introgresses resistance allele genes from IT97K-556-6 into susceptible local blackeye varieties (CB27) by backcrossing with the help of recombinant inbred line (RIL) for aphid resistance (Huynh et al. 2015). Genome solution for a major QTL associated with the $R k$ locus in cowpea for resistance to root-knot nematodes Meloidogyne spp. has significance for plant breeding programs and characterization R gene by Huynh et al. (2016). Muchero et al. (2010), working on the cross from the foliar thrips susceptible IT93K503-1 and the resistant black-eyed cowpea cultivar "California Blackeye No. 46" (CB46), identified three QTLs on the linkage groups 5 and 7. These QTLs' (Thr- 1, Thr-2, and Thr-3) peaks were collocated with the AFLP markers ACCCAT7, ACG-CTC5, and AGG-CAT1 and were linked with foliar damage caused by $T$. tabaci and F. schultzei. These urging researches paved the way forward for genetic characterization of major insect pest resistance in cowpea and disease causes $>15 \%$ yield loss in West Africa and impacts production in Asia and South America negatively. In addition, other putative candidate marker-assisted selection (MAS) for insect or disease resistance in cowpea was reported (Timko and Singh 2008).

Resistance to bruchid has been reported in few mung bean cultivars (Somta et al. 2006; Somta et al. 2008); however, some of mung bean breeders have keen interest in identifying new sources of resistance to this important pest from other Asian Vigna species such as V. umbellata and V. nepalensis (Pandiyan et al. 2010; Somta et al. 2008). It is reported that the bruchid and mung bean bug were controlled by a single dominant gene in the F1 and F2 seeds of mung bean and two QTLs were identified for bruchid resistance, and a QTL for bean bug resistance was detected. 
These new markers will be further used for cloning of the resistance genes to bruchid and bean bug in the future (Hong et al. 2015). There are several reports analyzing resistance to mung bean yellow mosaic virus (MYMV) in different germplasms, and both recessive and dominant genes have been implicated. The resistant variety SML-668 has two recessive genes for resistance. Sudha et al. (2013) reported that the resistance of mung bean variety "KMG189" is controlled by a single recessive gene. Development of mung bean yellow mosaic Indian virus (MYMIV) resistance, either using the wild mung bean accessions ( $V$. radiata var. sublobata) or some of the breeding line from Pakistan, has found a common major resistance QTL (variously named MYMIV'9_25, qMYMIV1, qMYMIV4) (Chen et al. 2013; Kitsanachandee et al. 2013). This locus was detected in different locations/regions, years, sources of resistance, and scoring systems. The locus was having specific markers; therefore, these could be used in marker-assisted selection for resistance breeding program.

The mung bean yellow mosaic virus resistance (MYMIV) has been found in some accession of black gram, and this resistance gene has been further mapped using SSR markers (Gupta et al. 2013). An SSR marker nearly linked to the resistant locus was found that could be used for marker-assisted selection. Kushida et al. (Kushida et al. 2013) recently studied some accessions of V. minima, and V.nakashimae showed a high level of resistance to all races of soybean cyst nematodes in Japan, and these resistant sources are being used in azuki breeding, since the soybean cyst nematode is an increasingly problematic pest on legumes in Hokkaido, Japan. V. nakashimae has been used to develop an interspecific linkage map with $V$. umbellata (Somta et al. 2006). QTL-M and QTL-E enhance soybean resistance to major insects; pyramiding these QTLs with cry1Ac increases protection against Bt-tolerant pests, presenting an opportunity to effectively deploy Bt with host plant resistance genes (Ortega et al. 2016).

\subsection{Transgenic Resistance to Insects}

The first successful genetic transformation of chickpea with crylAc gene, which inhibit the growth and development of $H$. armigera, was reported by Kar et al. (1997). Genetic transformation of chickpea using CrylAc gene has been reported by many workers subsequently (Indurker et al. 2007; Mehrotra et al. 2011). A second gene, Cry2Aa, was also incorporated for pyramiding with existing CrylAc in chickpea lines (Acharjee et al. 2010). Mehrotra et al. (2011) generated pyramided genes $C r y l A c$ and CrylA $b$ chickpea; however, pyramiding of two or more combination of genes with different modes of action is preferred for effective management of the insect pest. Ganguly et al. 2014 reported chickpea expressing fused crylAb/Ac constitutively for resistance to $H$. armigera using pod-specific $m s g$ promoter from soybean to different transgenic lines has also been reported. Homologous ubiquitin and RuBisCO small subunit ( $r b c S$ ) promoters used to transcribe crylAc in transgenic chickpea both constitutively and in a tissue-specific manner through Agrobacteriummediated transformation of chickpea var. ICCV89314 (Chakraborty et al. 2016). 
The toxicity of commercial Bt formulation and Cry1Ab and Cry1Ac to H. armigera larvae was reduced significantly when the $H$. armigera larvae were fed on diets amended with antibiotics, suggesting that gut microbes may be one of the factors conferring resistance/susceptibility to insects in $B t$ transgenic crops (Paramasiva et al. 2014).

In recent days, Cowpea aphid, $A$. cracciovra, also causes significant yield losses in chickpea, an important pulse crop in the Indian subcontinent, where transgenic chickpeas expressing the Allium sativum leaf agglutinin (ASAL) gene resulted in a significant reduction in survival and fecundity of cowpea aphid (Chakraborti et al. 2009). A new management strategy such as upregulating secondary metabolites, which are toxic to insect pests (Gatehouse 2002), or introducing RNAi technology for insect control by silencing endogenous genes of insects could be new strategy to develop genetically modified chickpea (Gordon and Waterhouse 2007).

Transgenic pigeon pea plants with crylAb and soybean trypsin inhibitor ( $S B T I)$ genes have been reported (Sharma et al. 2006) but have not been found to be effective for controlling $H$. armigera (Gopalaswamy et al. 2008). Developed transgenic chickpea expressing cowpea trypsin inhibitor (Thu et al. 2003) and $\alpha$-amylase inhibitor (Shade et al. 1994; Schroeder et al. 1995; Sarmah et al. 2004) showed resistance to bruchid species. Transgenic pea with expression of $\alpha$-amylase inhibitor has also been developed for resistance to pea weevil (Morton et al. 2000).

Ikea et al. (2003) detailed the fruitful hereditary change of cowpea utilizing the molecule particle gun bombardment of shoot meristem system. A productive and stable cowpea change/recovery framework has been created as of late (Popelka et al. 2006), so that transgenic cowpea is currently a reality. By and by, there is no distinguished cowpea assortment indicating solid imperviousness to bruchids. Interestingly, high resistance was depicted in the wild relative Vigna vexillata; however, nonviable seeds coming about because of their cross make this approach improper to exchange these qualities to the developed species (Fatokun 2002). Be that as it may, fake eating regimen bioassay performed on cowpea weevils recommended that $\alpha$-amylase inhibitor 1 ( $\alpha \mathrm{AI}-1$ ) confined from regular bean (Phaseolus vulgaris) would be utilized against these vermin assaults (Ishimoto et al. 1999).

Right now, huge advance has been made on cowpea hereditary change which may turn out to be without further ado accessible for the African ranchers. The qualities utilized are the Cry1 Ab communicating the delta endotoxin of Bacillus thuringiensis (Bt) ssp. kurstaki and the $\alpha$-amylase inhibitor 1 ( $\alpha \mathrm{AI}-1$ ) to target, individually, the unit borer (M. vitrata) and C. maculatus and C. chinensis (Abrol 1999; Popelka et al. 2006; Tarver et al. 2007; Adesoye et al. 2008; Huesing et al. 2011). Every one of these reviews permitted Solleti et al. (2008) to present the $\alpha$ AI-1 quality under bean phytohemagglutinin promoter, in "Pusa Komal," a financially imperative Indian cultivar, and to create fruitful transgenic plants which unequivocally restrained the improvement of $C$. maculatus and $C$. chinensis in insect bioassay. Due to the outcrossing observed among crops and crop to wild, the introduction of transgenic cowpea harboring insect-resistant gene in African agriculture would be a threat for the non-GM crop and their wild relatives (Williams and Chambliss 1980; Asiwe 2009). Lüthia et al. (2013) who preceded $\alpha A I-1$ gene is a cotyledon-specific promoter into the breeding line IT86D-1010 and the Japanese cultivar "Sasaque" 
that both showed $100 \%$ larval (C. chinensis and C. maculatus) mortality in the seeds of transgenic lines. Currently, several genes of interest such as herbicide imazapyr, $\alpha$-amylase inhibitor 1 (against bruchids), Cry1Ab, and Cry1Ac (against Maruca) have been brought in successfully into commercially important cultivars of cowpea, and the genes are transmitted in Mendelian fashion (Abaye et al. 2014). Investigations executed by Jackai et al. (1997) showed that the insect pests of cowpea controlled by several other different forms of Bt crystal toxins and this basic information was further used by Adesoye et al. (2008) and Bakshi et al. (2011) to introduce CrylAb in cultivars (TVu 201, Ife Brown, IT90K-277-2, IT90K-288, and IT90K- 391) and CrylAc genes in cultivar (Pusa Komal) in various cowpea genotypes, and their experiment results showed that the transgenes were carried in Mendelian fashion to the progenies which showed significant reduction of larvae survival and weight. These findings were confirmed by several other authors as the introduction of this gene in pea (Shade et al. 1994; Schroeder et al. 1995; Morton et al. 2000; Sousamajer et al. 2007), adzuki bean (Ishimoto et al. 1996), and chickpea (Sarmah et al. 2004; Ignacimuthu and Prakash 2006) conferred resistance against bruchid beetles.

\subsection{Potential and Limitations of HPR to Insects in Grain Legumes}

Crop protection includes application of synthetic pesticides, weedicides, etc. for protecting crops against pests and diseases and has largely been helpful in curbing the losses; however, their haphazard application leads to an adverse effect on environment and health hazards in human beings. The crop improvement efforts have been underway over a long period to develop varieties/cultivars with resistance to insect pests in grain legumes (Sharma 2005, 2016). Nevertheless, host plant resistance can be used as a primary constituent of pest control, as along with cultural, biological, and chemical control and as a check against the released susceptible cultivars, apart from the use of molecular approaches for the development of insect pests resistant cultivars of legumes. Adaptation of genetic alternatives, such as introgression/pyramiding of genes/quantitative trait loci associated, wide hybridization, and marker-assisted selections for development of insect pest-resistant cultivars, on the other hand, is much an ecological and eco-friendly approach (Khera et al. 2013). Special importance has been given on the current status and prospects of deploying newer molecular host plant resistance techniques and breeding approaches for developing improved cultivars with high resilience to major insect pests stress to achieve maximum genetic yield potential in all the legume crops. As we know, plant resistance to insects is the key factor of any pest management system because:

- It is specific to target insects or group of pests and generally has no adverse effects on the nontarget organisms in the ecosystem.

- Plant resistance effects on insect pest population are cumulative over sequential generations for particular pest because of bringdown survival, delayed development, and lower fecundity. 
- The most of insect-resistant crop cultivars carry moderate to high level of resistance across cropping season. In contrast, the insecticides must be applied frequently in order achieve satisfactory control of pest populations.

- HPR is easy to be compatible with other strategies of pest control, and it also improves the efficiency of other methods of pest management.

However, host plant resistance is not the only nostrum for solution for all the insect pest problems in agroecosystem. It needs a long time for the exploitation of plant genotypes/cultivars with resistance to insect pests. Some mechanisms of plant resistance may involve the diversion of plant morphological traits or biochemical traits for the production of defense chemicals and other physiological processes that helps in obtaining yield (Mooney et al. 1983). Although concentration of natural defense chemicals responsible for resistance is low in plant tissues, the total amount per hectare may be high (Mitra and Bhatia 1982). Some plant defense chemicals also affect the food nutrition quality. Most of genotypes with resistance to H. armigera are susceptible to Fusarium wilt in both pigeon pea and chickpea (Sharma 2005). There is a need to generate baseline information on the inheritance of resistance to insect pests in grain legumes and the host plant-insect-environment interactions to understand the genetic control of different mechanisms of resistance for the development of suitable strategies to increase the levels and diversify the basis of resistance for sustainable production of grain legumes. There is a necessity to break the linkage between the parameters conferring resistance to the target insect pests and the low-yield trait that results in susceptibility and at the same time do not have a negative effect on the quality of the product.

\subsection{Conclusions}

Conventional methods of protecting the legume crops from insect pests are inadequate to meet the growing demand for pulses in future. Accuracy and preciseness of phenotyping for resistance to insect pests remain a major critical limitation. Improved higher-version phenotyping systems will have a substantial impact on both MAS and conventional breeding in order to develop cultivars resistant to insect pests, in addition to there is a need of more strategic research that feeds into these endeavors. There are very limited reports concerning about the role of application of MAS for developing resistant cultivars in grain legumes. Be that as it may, those accessible neglects to exhibit an expansion in proficiency of MAS over conventional breeding methodologies. A combination of morphological, biochemical, and molecular markers is needed to introgress insect resistance genes from both cultigens germplasm and wild relatives of grain legumes to accelerate the process of developing cultigens with resistance to enhance the crop productivity and improve the livelihoods of the farming community. 


\section{References}

Abaye F, Badiane MD et al (2014) Cowpea. In: Singh M, Bisht IS, Dutta M (eds) Broadening the genetic base of grain legumes. Springer, New Delhi, pp 95-114

Abrol DP (1999) Pulse susceptibility to Callosobruchus chinensis (L) (Bruchidae: Coleoptera) under field conditions. Trop Agric 76:150

Acharjee S, Sarmah BK, Kumar PA et al (2010) Expression of a sequence-modified cry2Aa gene for resistance to H. armigera in chickpea (Cicer arietinum L.) Pl Sci 178(3):333-339

Adesoye A, Machuka J, Togun A (2008) CRY 1AB transgenic cowpea obtained by nodal electroporation. Afr J Biotechnol 7(18):3200-3210

Anonymous (2009) Report of expert group on pulses. Department of Agriculture \& Co-operation, Ministry of Agriculture, Government of India, New Delhi, pp 1-148

Anonymous (2011) IIPR Vision 2030. ICAR-Indian Institute of Pulses Research, Kanpur

Anonymous (2016) Report of expert group on pulses. Department of Agriculture \& Co-operation/ Ministry of Agriculture, Government of India, New Delhi, pp 1-148

Aryamanesh N, Byrne O, Hardie DC et al (2012) Large-scale density-based screening for pea weevil resistance in advanced backcross lines derived from cultivated field pea (Pisum sativum) and Pisum fulvum. Crop Pasture Sci 63:612-618

Aryamanesh N, Zeng Y, Byrne $\mathrm{O}$ et al (2014) Identification of genome regions controlling cotyledon, pod wall/seed coat and pod wall resistance to pea weevil through QTL mapping. Theor Appl Genet 127:489-497

Asiwe J (2009) Insect mediated out crossing and gene flow in cowpea (Vigna unguiculata (L.) Walp.): implication for seed production and provision of containment structures for genetically transformed cowpea. Afr J Biotechnol 8:226-230

Auclair JL (1963) Aphid feeding and nutrition. Annu Rev Entomol 8:439-490

Babb SL, Muehlbauer FJ (2005) Interspecific cross incompatibility in hybridizations between Cicer arietinum L. and C. anatolicum Alef. In: Proceedings of the XIII plant and animal genome conference, San Diego, 15-19 Jan, www.intl.pag.org/13/abstracts/PAG13_PG472.html

Bakshi S, Sadhukhan A, Mishra S et al (2011) Improved Agrobacterium-mediated transformation of cowpea via sonication and vacuum infiltration. Pl Cell Rep 30:2281-2292

Ballhorn DJ, Kautz S, Jensen M et al (2011) Genetic and environmental interactions determine plant defenses against herbivores. Ecology 99:313-326

Basandrai AK, Basandrai D, Duraimurugan P et al (2011) Breeding for biotic stresses. In: Pratap A, Kumar J (eds) Biology and breeding of food legumes. Crop Improvement Division, Indian Institute of Pulses Research, Kanpur, pp 220-240

Benchasri S, Nualsri C, Santipracha Q, et al. (2007) Evaluation of aphid (Aphis craccivora Koch) resistance in 24 accessions of yardlong bean and cowpea. In: Proceeding of the 1st Joint PSUUNS International conference on bioscience: food, agriculture, and the environment, Songkhla, 17-19 August, pp 215-222

Bhagwat VR, Aherker SK, Satpute VS et al (1995) Screening of chickpea (Cicer arietinum L.) genotypes for resistance to Helicoverpa armigera ( $\mathrm{Hb}$.) and its relationship with malic acid in leaf exudates. J Entomol Res 19:249-253

Bhalla S, Kapur ML, Singh C et al (2004) Interception of bruchids in imported lentil (Lens spp) germplasm. Indian J Agric Sci 74:332-333

Bhora A, Pandey MK, Jha UC et al (2014) Genomics assisted breeding in four major pulse crops of developing countries: present status and prospects. Theor Appl Genet 127:1263-1291

Blair MW, Muňoz C, Buendía HF et al (2010) Genetic mapping of microsatellite markers around the arcelin bruchid resistance locus in common bean. Theor Appl Genet 121:393-402

Boerjan W, Ralph J, Baucher M (2003) Lignin biosynthesis. Annu Rev Plant Biol 54:519-546

Borges M, Moraes MCB, Laumann RA et al (2011) Chemical ecology studies in soybean crop in brazil and their application to pest management. In: Ng T-B (ed) Soybean-biochemistry, chemistry and physiology. InTech Publishing, Rijeka, pp p31-p66 
Bouhssini ME, Sarker A, Erskine W et al (2008) First sources of resistance to Sitona weevil (Sitona crinitus Herbst) in wild Lens species. Genet Resour Crop Evol 55:1-4

Bray AL, Lailb LA, John N et al (2016) Phenotyping techniques and identification of soybean resistance to the Kudzu bug. Crop Sci. doi:10.2135/cropsci2015.09.0536

Byrne O, Galwey N, Hardie D (2002) Searching for molecular markers for resistance to pea weevil. In: McComb JA (ed) Plant breeding for the 11th millennium. In: Proceedings of the 12th Australasian plant breeding conference, Australian Plant Breeding Association, Perth, pp 362-366

Byrne OM, Hardie DC, Khan TN et al (2008) Genetic analysis of pod and seed resistance to pea weevil in a Pisum sativum $\times$ P. fulvum interspecific cross. Aust J Agric Res 59:854-862

Chakraborti D, Sarkar A, Mondal HA et al (2009) Tissue specific expression of potent insecticidal, Allium sativum leaf agglutinin (ASAL) in important pulse crop, chickpea (Cicer arietinum L.) to resist the phloem feeding Aphis craccivora. Transgen Res 18:529-544

Chakraborty J, Senjuti S, Prithwi G et al (2016) Homologous promoter derived constitutive and chloroplast targeted expression of synthetic cry1 Ac in transgenic chickpea confers resistance against Helicoverpa armigera. Plant Cell Tiss Organ Cult 125:521-535

Chanchal S, Singh NN (2014) Evaluation of responses of cowpea (Vigna unguiculata Walpers) genotypes to infestation of legume pod borer (Maruca vitrata Fabricius). J Fd Leg 27(4):334-339

Channarayappa SG, Muniyappa V, Frist RH (1992) Resistance of Lycopersicon species to Bemisia tabaci, a tomato leaf curl virus vector. Canad J Bot 70:2184-2192

Chaturvedi SK, Gurha SN, Shivsewak R et al (1998) Possible combined resistance against Fusarium wilt and pod borer in chickpea (Cicer arietinum L.) Indian J Pulses Res 11:117-119

Chen HM, HS K, Schafleitner R et al (2013) The major quantitative trait locus for mungbean yellow mosaic Indian virus is tightly linked in repulsion phase to the major bruchid resistance locus in a cross between mungbean [ Vigna radiata (L.) Wilczek] and its wild relative Vigna radiata ssp. sublobata. Euphytica 192:205-216

Chhabra KS (1981) Mechanism of insect-pest resistance in pulse crops. In: Gill KS (ed) Breeding methods for the improvement of pulse crops. Kalyani Publishers, Ludhiana, pp 142-160

Chhabra KS, Kooner BS, Sharma AK et al. (1988) Sources of resistance in mungbean (Vigna radiata) to insect pests and mungbean yellow mosaic virus In: Proceedings of the II international symposium on mungbean, vol 16-20, Bangkok, pp 308-314

Chhabra KS, Sharma AK, Saxena AK et al (1990) Sources of resistance in chickpea: role of biochemical components of the incidence of gram pod borer Helicoverpa armigera (Hubner). Ind J Entomol 52:423-430

Chiang HS, Singh SR (1988) Pod hairs as a factor in Vigna vexillata resistance to the pod-sucking bug, Clavigralla tomentosicollis. Entomol Exp Appl 47:195-199

Cho S, Kumar J, Shultz J, Anupama K et al (2002) Mapping genes for double podding and other morphological traits in chickpea. Euphytica 128:285-292

Chopra N, Rajni HR (1987) Resistance to different lentil varieties to attack of Bruchids lentis. LENS Newsl 14:23-27

Chotechung S, Somta P, Chen J et al. (2016) A gene encoding a polygalacturonase-inhibiting protein (PGIP) is a candidate gene for bruchid (Coleoptera: bruchidae) resistance in mungbean (Vigna radiata). Theor Appl Genet. doi:10.1007/s00122-016-2731-1

Choudhary AK, Raje RS, Datta S et al. (2013) Conventional and molecular approaches towards genetic improvement in pigeonpea for insect resistance. Am J Plant Sci Suppl Spec Issue Biointeract Plant Health 4.2A:372-385

Clement SL, Quisenberry SS (eds) (1999) Global plant genetic resources for insect-resistant crops. CRC Press, Boca Raton

Clement SL, Sharaf El-Din N, Weigand S et al (1994) Research achievement in plant resistance to insect pests of cool season food legumes. Euphytica 73:41-50

Clement SL, Wightman JA, Hardie DC et al (2000) Opportunities for integrated management of insect pests of grain legumes. In: Linking research and marketing opportunities for pulses in the 21 st century. Kluwer, Dordrecht, pp 467-480 
Clement SL, Hardie DC, Elberson LR (2002) Variation among accessions of Pisum fulvum for resistance to pea weevil. Crop Sci 42:2167-2173

Clement SL, McPhee KE, Elberson LR et al (2009) Pea weevil, Bruchus pisorum L. (Coleoptera: Bruchidae), resistance in Pisum sativum Pisum fulvum interspecific crosses. Pl Breed 128:478-485

Clements T, John A, Nielsen K et al (2008) Translinks case study: Tmatboey community-based ecotourism project, Cambodia. Wildlife Conservation Society, New York

Costa EN, Souza BHS, Bottega DB, et al. (2013) Diverg^encia gen_etica de gen_otipos de feijoeiro a infestaç ao de Zabrotes subfasciatus (Bohemann) (Coleoptera: Bruchidae). Semina $34: 2737 \mathrm{e} 2752$

Cotter SC, Edwards OR (2006) Quantitative genetics of preference and performance on chickpeas in the noctuid moth, Helicoverpa armigera. Heredity 96:396-402

Cowgill SE, Lateef SS (1996) Identification of antibiotic and antixenotic resistance to Helicoverpa armigera (Lepidoptera: Noctuidae) in chickpea. J Econ Entomol 89:224-229

Cruz PL, Edson LL, Baldin M d J (2014) Characterization of antibiosis to the silverleaf whitefly Bemisia tabaci biotype B (Hemiptera: Aleyrodidae) in cowpea entries. J Pest Sci 87:639-645

Dabrowski ZT, Bungu DOM, Ochieng RS (1983) Studies on the legume pod-borer, Maruca testulalis (Geyer) Methods used in cowpea screening for resistance. Insect Sci Appl 4:141-145

Das SB, Kataria VP (1999) Relative susceptibility of chickpea genotypes against pod borer Helicoverpa armigera (Hübner). Insect Environ 5(2):68-69

Dawoodi JT, Parsana GJ, Jethva DM, Virani VR (2009) Seasonal incidence of pink pod borer, Cydia ptychora (Meyrick) in blackgram. Insect Environ 15:137-138

Dawoodi JT, Parsana GJ, Jethva DM et al (2010) Screening of blackgram varieties for resistance against pink pod borer, Cydia ptychora (Meyrick). Legume Res 33:54-56

Deshmukh RB, Patil VJ (1995) Genetic architecture of yield and its components in chickpea. Legume Res 18(2):85-88

Devasthali S, Joshi M (1994) Infestation and varietal preference of insect pests in green gram. Indian Agric 38:263-272

Devesthali S, Saran RK (1998) Relative susceptibility of new cultivars of green gram (Vigna radiata L. Wilczek) to insect pests at Indore (M.P.) Indian Agric 42:261-266

Dhaliwal GS, Jindal V, Mohindru B (2015) Crop losses due to insect pests: global and Indian scenario. Indian J Entomol 77(2):165-168

Dhillon MK, Sharma HC (2012) Paradigm shifts in research on host plant resistance to insect pests. Indian J Pl Prot 40(1):1-11

Dixit GP (2015) All India Coordinated Research Project on Chickpea. Project Coordinator's report. Available at: www.Aicrpchickpea.res.in/pdf_files/pc_report2014_190915.pdf

Dongre TK, Pawar SE, Thakare RG et al (1996) Identification of resistant sources to cowpea weevil (Callosobruchus maculatus (F.)) in Vigna sp. and inheritance of their resistance in black gram (Vigna mungo var. mungo). J Stored Prod Res 32:201-204

Dougherty DE (1976) Pinitol and other soluble carbohydrates in soybean as factors in facultative parasite nutrition. Dissertation, University of Georgia, Tifton

Dua RP, Gowda CLL, Shiv Kumar H et al (2005) Breeding for resistance to Helicoverpa: effectiveness and limitations. In: Sharma HC (ed) Heliothis/Helicoverpa management: emerging trends and strategies for future research. Oxford \& IBH, New Delhi, pp 307-328

Durairaj C, Sharma HC, Kalaimagal T et al (2009) A record on the insect pests of wild relatives of pigeonpea, mungbean and urdbean. J Fd Leg 22(2):146-148

Echendu TNC, Akingbohungbe AE (1989) The larval population and plant growth phase for screening cowpea for resistance to Maruca testulalis (Geyer) (Lepidoptera: Pyralidae) in Nigeria based on flower, pods and yield loss. Trop Pest Manag 35:173-175

Erskine WM, Tufail MC, Russell MM et al (1994) Current and future strategies in breeding lentil for resistance to biotic and abiotic stresses. Euphytica 73:127-135

Fatokun CA (2002) Breeding cowpea for resistance to insect pests: attempted crosses between cowpea and V. vexillata. In: Fatokun CA, Tarawali SA, Singh BB et al. (eds) Challenges and 
opportunities for enhancing sustainable cowpea production. Proceedings of the world cowpea conference III, International Institute of Tropical Agriculture, Ibadan, p 4-8

Fehr WR (1987) Principles of cultivar development, vol 1. Theory and Technique Macmillan, New York

Food and Agriculture Organization (2012) Production statistics. FAO, Rome

Fujii K, Miyazaki S (1987) Infestation resistance of wild legumes (Vigna sublobata) to azuki bean weevil, Callosobruchus chinensis and its relationship with cytogenetic classification. Appl Entomol Zool 22:229-230

Ganguly M, Molla A, Karmakar S et al (2014) Development of pod borer resistant transgenic chickpea using a pod specific and a constitutive promoter driven fused $c r y 1 A b / A c$ gene. Theor Appl Genet 127:2555-2565

Gatehouse JA (2002) Plant resistance towards insect herbivores: a dynamic interaction. New Phytol 156:145-169

Giri AP, Kachole MS (1998) Amylase inhibitors of pigeonpea (Cajanus cajan) seeds. Phytochem 47:197-202

Girija SPM, Gowda CLL et al (2008) Biophysical and biochemical basis of host plant resistance to pod borer (Helicoverpa armigera) in chickpea (Cicer arietinum L.) Indian J Genet 68:320-323

Gopalaswamy SVS, Sharma HC, Subbaratnam GV et al (2008) Field evaluation of transgenic pigeonpea plants for resistance to Helicoverpa armigera. Indian J Pl Prot 36:228-234

Gordon KHJ, Waterhouse PM (2007) RNAi for insect-proof plants. Nat Biotechnol 25:1231-1232

Gowda CLL, Lateef SS, Smithson JB et al. (1983) Breeding for resistance to Heliothis armigera in chickpea. In: Proceedings of the national seminar on breeding crop plants for resistance to pests and diseases, School of Genetics, Tamil Nadu Agricultural University, Coimbatore, 25-27 May, pp 36-39

Gowda CLL, Ramesh S, Chandra S et al (2005) Genetic basis of pod borer (Helicoverpa armigera) resistance and grain yield in desi and Kabuli chickpea (Cicer arietinum L.) under unprotected conditions. Euphytica 145:199-214

Green PWC, Stevenson PC, Simmonds MSJ et al (2002) Can larvae of the pod-borer, Helicoverpa armigera (Lepidoptera: Noctuidae), select between wild and cultivated pigeonpea [Cajanus sp. (Fabaceae)]. Bull Entomol Res 92:45-51

Green PWC, Stevenson PC, Simmonds MSJ et al (2003) Phenolic compounds on the pod-surface of pigeonpea, Cajanus cajan, mediate feeding behavior of Helicoverpa armigera larvae. J Chem Ecol 29:811-821

Green PWC, Sharma HC, Stevenson PC et al (2006) Susceptibility of pigeonpea and some of its wild relatives to predation by Helicoverpa armigera: implications for breeding resistant cultivars. Crop Pasture Sci 57:831-836

Gupta S, Gupta DS, Anjum TK et al (2013) Inheritance and molecular tagging of MYMIV resistance gene in blackgram (Vigna mungo L. Hepper). Euphytica 193:27-37

Harborne JB, Williams CA (2000) Advances in flavonoid research since 1992. Phytochem 55:481-504

Harminder K, Gupta SK, Daljeet S et al (2005) Preliminary evaluation of chickpea genotypes for resistance to pod borer and wilt complex. Internat Chickpea Pigeonpea Newsl 12:39-41

Harsulkar AM, Giri AP, Patankar A et al (1999) Successive use of non-host plant proteinase inhibitors required for effective inhibition of Helicoverpa armigera gut proteinases and larval growth. Pl Physiol 121:497-506

Herselman L, Thwaites R, Kimmins FM et al (2004) Identification and mapping of AFLP markers linked to peanut (Arachis hypogaea L.) resistance to the aphid vector of groundnut rosette disease. Theor Appl Genet 109:1426-1433

Hoffmann-Campo CB, Neto JAR, Oliveira MCN et al (2006) Detrimental effect of rutin on Anticarsia gemmatalis. Pesqui Agropecu Brasileira 41:1453-1459

Hong MI, Kim KH, JH K et al (2015) Inheritance and quantitative trait loci analysis of resistance genes to bruchid and bean bug in mungbean (Vigna radiata L. Wilczek). Pl Breed Biotech 3(1):39-46 
Horber E (1978) Resistance of pests of grain legumes in the USA. In: Singh SR, van HF E, Taylor JA (eds) Pests of grain legumes: ecology and control. Academic, London, pp 281-295

Huesing J, Romeis J, Ellstrand N et al (2011) Regulatory considerations surrounding the deployment of Bt-expressing cowpea in Africa: report of the deliberations of an expert panel. GM Crops 2(3):211-214

Hulburt DJ, Boerma HR, All JN (2004) Effect of pubescence tip on soybean resistance to lepidopteran insects. J Econ Entomol 97:621-627

Huynh B, Jeffrey DE, Arsenio N et al (2015) Genetic mapping and legume synteny of aphid resistance in African cowpea (Vigna unguiculata L. Walp.) grown in California. Mol Breed 35:36

Huynh BL, Matthews WC, Ehlers JD et al (2016) A major QTL corresponding to the $R k$ locus for resistance to root-knot nematodes in cowpea (Vigna unguiculata L. Walp.) Theor Appl Genet 129:87-95

Ignacimuthu S, Prakash S (2006) Agrobacterium- mediated transformation of chickpea with $\alpha$-amylase inhibitor gene for insect resistance. J Biosci 31:33

Ikea J, Ingelbrecht I, Uwaifo A et al (2003) Stable gene transformation in cowpea (Vigna unguiculata L. Walp.) using particle gun method. African J Biotechnol 2:211-218

Indurker S, Misra HS, Eapen S (2007) Genetic transformation of chickpea (Cicer arietinum L.) with insecticidal crystal protein gene using particle gun bonbardment. Pl Cell Rep 26:755-763

International Crops Research Institute for the Semi-Arid Tropics (1992) The medium-term plan. ICRISAT, Patancheru

Ishaaya I, Hirashima A, Yablonski S (1991) Mimosine, a nonprotein amino acid, inhibits growth and enzyme systems in Tribolium castaneum. Pestic Biochemi Physiol 39:35-42

Ishimoto M, Sato T, Chrispeels MJ et al (1996) Bruchid resistance of transgenic azuki bean expressing seeds $\alpha$-amylase inhibitor of the common bean. Entomol Exp Appl 79:309-315

Ishimoto M, Yamada T, Kaga A (1999) Insecticidal activity of an $\alpha$-amylase inhibitor-like protein resembling a putative precursor of $\alpha$-amylase inhibitor in the common bean, Phaseolus vulgaris L. Biochim Biophys Acta 1432:104-112

Jackai LEN (1981) Relationship between cowpea crop phenology and field infestation by the legume pod borer, Maruca testulalis. Ann Entomol Soc America 74:402-408

Jackai LEN (1982) A field screening technique for resistance of cowpea (Vigna unguiculata) to the pod borer Maruca testulalis (Geyer) (Lepidoptera: Pyralidae). Bull Entomol Res 72:145-156

Jackai LEN, Adalla CB (1997) Pest management practices in cowpea: a review. In: Singh BB, Mohan Raj DR, Dashiell KE (eds) Advances in cowpea research. International Institute of Tropical Agriculture and Japan International Research Center for Agricultural Sciences. Sayce Publishing, Devon, pp 240-257

Jackai LEN, Oghiakhe S (1989) Podwall trichomes and resistance of two wild cowpea, Vigna vaxillata, accessions to Maruca testulalis (Geyer) (Lepidoptera: Pyralidae) and Clavigralla tomentosicollis Stal. (Hemiptera: Coreidae). Bull Entomol Res 79:595-605

Jadhav SD, Vijaykumar LG (2015) Genetics of traits associated with pod borer resistance and seed yield in chickpea (Cicer arietinum L.) Iranian J Genet Pl Breed 4(1):9-16

Jadhav DR, Mallikarjuna N, Rathore A et al (2012a) Effect of some flavonoids on survival and development of Helicoverpa armigera (Hübner) and Spodoptera litura (Fab) (Lepidoptera: Noctuidae). Asian J Agric Sci 4(4):298-307

Jadhav DR, Mallikarjuna N, Sharma HC et al (2012b) Introgression of Helicoverpa armigera resistance from Cajanus acutifolius -a wild relative from secondary gene pool of pigeonpea (Cajanus cajan). Asian J Agric Sci 4(4):242-248

Johnson B (1953) The injurious effects of the hooked epidermal hairs of the French beans (Phaseolus vulgaris L.) on Aphis craccivora Koch. Bull Entomol Res 44:779-788

Jukanti AK, Gaur PM, Gowda CLL et al (2012) Nutritional quality and health benefits of chickpea (Cicer arietinum L.): a review. Brit J Nutr 108:S11-S26

Kaga A, Ishimoto M (1998) Genetic localization of a bruchid resistance gene and its relationship to insecticidal cyclopeptide alkaloids, the vignatic acids in mungbean (Vigna radiata L.Wilczek). Mol Gener Genet 258:378-384 
Kalariya GB, Judal GS, Patel GM (1998) Reaction of pigeonpea genotypes against important insect pests. Gujarat Agric Uni Res J 23:33-38

Kamphuis L, Gao L, Singh K (2012) Identification and characterization of resistance to cowpea aphid (Aphis craccivora Koch) in Medicago truncatula. BMC Pl Biol 12:101

Kamphuis LG, Zulak K, Gao L-L et al (2013) Plant-aphid interactions with a focus on legumes. Funct Pl Biol 40:1271-1284

Kang YJ, Kim S, Kim MY et al (2014) Genome sequence of mungbean and insights into evolution within Vigna species. Nat Commun 5:5443. doi:10.1038/ncomms6443

Kansal R, Gupta RN, Koundal KR, Kuhar K, Gupta VK (2008) Purification, characterization and evaluation of insecticidal potential of trypsin inhibitor from mungbean (Vigna radiata L. Wilczek) seeds. Acta Physiol Pl 30:761-768

Kar S, Basu D, Das S et al (1997) Expression of CryIA(C) gene of Bacillus thurigenesis in transgenic chickpea plants inhibits development of pod borer (Heliothis armigera) larvae. Transgen Res 6:177-185

Karungi J, Adipala E, Nampala P et al (2000) Pest management in cowpea. Part 3. Quantifying the effect of field pests on grain yields in eastern Uganda. Crop Prot 19:343-347

Kaur L, Sirari A, Kumar D et al (2013) Harnessing Ascochyta blight and Botrytis grey mould resistance in chickpea through interspecific hybridization. Phytopathol Mediterr 52(1):157-165

Kester KM, Smith CM, Gilman DF (1984) Mechanisms of resistance in soybean (Glycine max [L.] Merrill) genotype PI 171444 to the southern green stink bug., Nezara viridula (L.) (Hemiptera: Pentatomidae). Environ Entomol 13(5):1208-1215

Khan ZR, Ward JT, Norris DM (1986) Role of trichomes in soybean resistance to cabbage looper, Trichoplusia ni. Entomol Exp Applic 42:109-117

Khera P, Upadhyaya HD, Pandey MK et al (2013) The Plant Genome 6. Crop Science Society of America, Madison. doi:10.3835/plantgenome2013.06.0019 9-345

Kitsanachandee R, Somta P, Chatchawankanphanich O et al (2013) Detection of quantitative trait loci for mungbean yellow mosaic India virus (MYMIV) resistance in mungbean (Vigna radiata (L.) Wilczek) in India and Pakistan. Breed Sci 63:367-373

Koona P, Osisanya EO, Jackai LEN et al (2002) Resistance in accessions of cowpea to the coreid pod-bug Clavigralla tomentosicollis (Hemiptera: Coreidae). J Econ Entomol 95:1281-1288

Kumar SS, Gupta S, Chandra S et al (2004) How wide is the genetic base of pulse crops. In: Ali M, Singh BB, Kumar S et al (eds) Pulses in new perspective. Indian Institute of Pulses Research, Kanpur, pp 211-221

Kumar J, Choudhary AK, Solanki RK et al (2011) Towards marker-assisted selection in pulses: a review. Pl Breeding 130:297-313

Kumari DA, Reddy DJ, Sharma HC (2006) Antixenosis mechanism of resistance in pigeonpea to the pod borer, Helicoverpa armigera. J Appl Entomol 130(1):10-14

Kumari DA, Reddy DJ, Sharma HC (2010a) Stability of Resistance to pod borer, Helicoverpa armigera in pigeonpea. Indian J Pl Protect 38(1):6-12

Kumari DA, Sharma HC, Reddy DJ (2010b) Incorporation of lyophilized leaves and pods into artificial diet to assess antibiosis component of resistance to pod borer in pigeonpea. J Fd Leg 23(1):57-65

Kushida A, Tazawa A, Aoyama S (2013) Novel sources of resistance to the soybean cyst nematode (Heterodera glycines) found in wild relatives of azuki bean (Vigna angularis) and their characteristics of resistance. Genetic Resour Crop Evol 60(3):985-994

Lakshminarayan S, Singh PS, Mishra DS (2008) Relationship between whitefly population, YMV disease and morphological parameters of green gram germplasm. Envirn Ecol 26:978-982

Lal SS (1987) Insect pests of mung, urd, cowpea and pea and their management. In: Rao MV, Sithanantham S (eds) Plant protection in field crops. Plant Protection Association of India, Hyderabad, pp 185-201

Lale NES, Kolo AA (1998) Susceptibility of eight genetically improved local cultivars of cowpea to Callosobruchus maculatus F. (Coleoptera: Bruchidae) in Nigeria. Int J Pest Manag 44:25-27 
Lambrides CJ, Imrie BC (2000) Susceptibility of mungbean varieties to the bruchid species Callosobruchus maculatus, C. phaseoli, C. chinensis and Acanthoscelides obtectus. Aust J Agric Res 51:85-89

Lateef SS (1985) Gram pod borer (Heliothis armigera Hub.) resistance in chickpea. Agric Ecosyst Environ 14:95-102

Lateef SS (1990) Scope and limitations of host plant resistance in pulses. In: Sachan JN (ed) First national workshop on Heliothis management: current status and future strategies. Directorate of Pulses Research, Kanpur, pp 129-140

Lateef SS, Pimbert MP (1990) The search for host plant resistance of Helicoverpa armigera in chickpea and pigeonpea at ICRISAT. In: Proceedings of the Consultative group meeting on the host selection behavior of Helicoverpa armigera, ICRISAT, Hyderabad, 5-7 March, pp 185-192

Lateef SS, Sachan JC (1990) Host-plant resistance to Helicoverpa armigera (Hub.) in different agro ecological contexts. In: Chickpea in the nineties, Proceedings of the second international workshop on chickpea, international crops research institute for the -semi-arid tropics/international center for agricultural research in the dry areas, pp 181-190.

Lawlor HJ, Siddique KHM, Sedgley RH (1998) Improving cold tolerance and insect resistance in chickpea and the use of AFLPs for the identification of molecular markers for these traits. Acta Hortic 461:185-192

Liu SH, Norris DM, Lyne P (1989) Volatiles from the foliage of soybean, Glycine max, and lima bean, Phaseolus lunatus: their behavioral effects on the insects Trichoplusia ni and Epilachna varivestis. J Agric Fd Chem 37:496-501

Lüthia C, Álvarez-Alfagemea F, Ehlersa JD et al (2013) Resistance of $\alpha$ AI-1 transgenic chickpea (Cicer arietinum) and cowpea (Vigna unguiculata) dry grains to bruchid beetles (Coleoptera: Chrysomelidae). Bull Entomol Res 103(04):373-381

Macfoy CA, Dabrowski ZT, Okech S (1983) Studies on the legume pod borer, Maruca testulalis (Geyer) - 4. Cowpea resistance to oviposition and larval feeding. Insect Sci Applic 4:147-152

Mallikarjuna N (2001) Prospects of using Cicer canariense for chickpea improvement. Internat Chickpea Pigeonpea Newsl 8:23-24

Mallikarjuna N, Sharma HC, Upadhyaya HD (2007) Exploitation of wild relatives of pigeonpea and chickpea for resistance to Helicoverpa armigera. SAT eJournal I ejournalicrisatorg 3(1):4-7

Mallikarjuna J, Ashok Kumar CT, Roshmi MA (2009) Studies on relationship of morphological characters with pod borer damage in Dolichos bean, Lablab purpureas L. Insect Environ 15:108-109

Mallikarjuna N, Saxena KB, Jadhav DR (2011a) Cajanus. In: Kole C (ed) Wild crop relatives: genomic and breeding resources. Springer, Berlin/Heidelberg, pp 21-33

Mallikarjuna N, Senapathy S, Jadhav DR et al (2011b) Progress in the utilization of Cajanus platycarpus (Benth.) Maesen in pigeonpea improvement. Plant Breed 30:507-514

Mallikarjuna N, Saxena KB, Lakshmi J et al (2012) Differences between Cajanus cajan (L.) Millspaugh and C. cajanifolius (Haines) van der Maesen, the progenitor species of pigeonpea. Genet Resour Crop Evol 59:411-417

Maxwell FG, Jennings PR (1980) Breeding plants resistant to insects. John Wiley, New York

Mehrotra M, Singh AK, Sanyal I et al (2011) Pyramiding of modified cry1Ab and cry1Ac genes of Bacillus thuringiensis in transgenic chickpea (Cicer arietinum L.) for improved resistance to pod borer insect Helicoverpa armigera. Euphytica 182:87-102

Mendesil E, Rämert B, Marttila S et al (2016) Oviposition preference of pea weevil, Bruchus pisorum L. among host and non-host plants and its implication for pest management. Frontiers Pl Sci 6. doi:10.3389/fpls.2015.01186

Mitra R, Bhatia CR (1982) Bioenergetic considerations in breeding for insect and pathogen resistance in plants. Euphytica 31:429-437

Mooney HA, Gulmon SL, Johnson ND (1983) Physiological constraints on plant chemical defenses. In: Hedin PA (ed) Plant resistance to insects, ACS Symposium Series 208. American Chemical Society, Washington, pp 21-36 
Morton RL, Schroeder HE, Bateman KS et al (2000) Bean alpha-amylase inhibitor 1 in transgenic peas (Pisum sativum) provides complete protection from pea weevil (Bruchus pisorum) under field conditions. Proc Nat Acad Sci USA 97:3820-3825

Moudgal RK, Lakra RK, Dahiya B et al (2008) Physico-chemical traits of Cajanus cajan (L.) Millsp. pod wall affecting Melanagromyza obtusa (Malloch) damage. Euphytica 161(3):429-436

Muchero W, Ehlers JD, Roberts PA (2010) QTL analysis for resistance to foliar damage caused by Thrips tabaci and Frankliniella schultzei (Thysanoptera: Thripidae) feeding in cowpea [ Vigna unguiculata (L.) Walp.] Mol Breed 25:47-56

Murray JD, Michaels TE, Cardona C et al (2004) Quantitative trait loci for leafhopper (Empoasca fabae and Empoasca kraemeri) resistance and seed weight in the common bean. Pl Breeding 123:474-479

Myers GO, Fatokun CA, Young ND (1996) RFLP mapping of an aphid resistance gene in cowpea (Vigna unguiculata L. Walp). Euphytica 91:181-187

Nanda UK, Sasmal A, Mohanty SK (1996) Varietal reaction of pigeonpea to pod borer Helicoverpa armigera (Hubner) and modalities of resistance. Curr Agric Res 9:107-111

Narayanamma Lakshmi V (2005) Genetics of resistance to pod borer, Helicoverpa armigera in chickpea (Cicer arietinum). Dissertation, ANGR Agricultural University, Hyderabad

Narayanamma VL, Sharma HC, Gowda CLL (2007) Mechanisms of Resistance to Helicoverpa armigera and introgression of resistance genes into F1 hybrids in chickpea. Arthropod-Pl Interact 1(4):263-270

Narayanamma VL, Gowda CLL, Sriramulu M et al (2013a) Nature of gene action and maternal effects for pod borer, Helicoverpa armigera resistance and grain yield in chickpea, Cicer arietnum. Amer J Pl Sci 4:26-37

Narayanamma VL, Sharma HC, Vijay PM et al (2013b) Expression of resistance to the pod borer Helicoverpa armigera (Lepidoptera: Noctuidae), in relation to high performance liquid chromatography fingerprints of leaf exudates of chickpea. Int J Trop Insect Sci 33:276-282

Nkansah PK, Hodgson CJ (1995) Interaction between aphid resistant cowpea cultivars and three clones of cowpea aphid and the effect of two light intensity regimes in this interaction. Internat J Pest Manag 41:161-165

Obadofin AA (2014) Screening of some cowpea varieties for resistance to Callosobruchus maculatus. Internat J Pure Appl Sci Technol 22(1):9-17

Oghiakh S, Odulaja A (1993) A multivariate analysis of growth and development parameters of the legume pod borer, Maruca testulalis on variably resistant cowpea cultivars. Entomol Exp Appl 66:275-282

Oghiakhe S (1995) Effect of pubescence in cowpea resistance to the legume pod borer, Maruca testulalis (Lepdioptera: Pyralidae). Crop Prot 14:379-387

Oghiakhe S, Jackai LEN, Makanjuola WA (1991) Cowpea plant architecture in relation to infestation and damage by the legume pod-borer, Maruca testulalis (Geyer) (Lepidoptera: Pyralidae)-1. Effect of canopy structure and pod position. Insect Sci Appl 12:193-199

Oghiakhe S, Jackai LEN, Makanjuola WA (1992a) A rapid visual field screening technique for resistance of cowpea (Vigna unguiculata) to the legume pod borer Maruca testulalis (Lepidoptera: Pyralidae). Bull Entomol Res 82:507-512

Oghiakhe S, Jackai LEN, Makanjuola WA (1992b) Cowpea plant architecture in relation to infestation and damage by legume pod borer, Maruca testulalis (Geyer) (Lepidoptera; Pyralidae). 3. Effect of plant growth habit. Insect Sci Appl 14:199-203

Okech SOH, Saxena KN (1990) Responses of Maruca testulalis (Lepidoptera: Pyralidae) larvae to variably resistant cowpea cultivars. Environ Entomol 19:1792-1797

Ombakho GA, Tyagi AP, Pathak RS (1987) Inheritance of resistance to the cowpea aphid in cowpea. Theor Appl Genet 74:817-819

Onyishi GC, Harriman JC, Ngwuta AA et al (2013) Efficacy of some cowpea genotypes against major insect pests in southeastern agro-ecology of Nigeria. Middle-East J Scientif Res 15(1):114-121

Ortega MA, John NA, Boerma HR et al (2016) Pyramids of QTLs enhance host-plant resistance and Bt-mediated resistance to leaf chewing insects in soybean. Theor Appl Genet 129:703-715 
Painter RH (1951) Insect resistance in crop plants. MacMillan, New York

Panda N, Khush GS (1995) Host plant resistance to insects. CAB International in association with International Rice Research Institute, Biddles, Guildford

Pandiyan M, Senthil N, Ramamoorthi N (2010) Interspecific hybridization of Vigna radiata $x 13$ wild Vigna species for developing MYMV donar. Electron J Pl Breed 1(4):600-610

Parade VD, Sharma HC, Kachole MS (2012) Protease inhibitors in wild relatives of pigeonpea against the cotton bollworm/legume pod borer, Helicoverpa armigera. Amer J Pl Sci 3:627-635

Paramasiva I, Sharma HC, Venkata Krishnayya P (2014) Antibiotics influence the toxicity of the delta endotoxins of Bacillus thuringiensis towards the cotton bollworm, Helicoverpa armigera. BMC Microbiol 14(200):1-11

Parmar BS, Walia S (2001) Prospects and problems of phytochemical biopesticides. In: Koul O, Dhaliwal GS (eds) Phytochemical biopesticides. Harwood, Amsterdam, pp 133-210

Parsai SK (1996) Studies on pod fly and pod borer damage in certain medium/late maturing varieties of pigeonpea. Bhartiya Krishi Anusandhan Patrika 11:117-120

Patankar AG, Harsulkar AM, Giri A et al (1999) Diversity in inhibitors of trypsin and Helicoverpa armigera gut proteinases in chickpea (Cicer arietinum) and its wild relatives. Theor Appl Genet 99:719-726

Pathak RS (1988) Genetics of resistance to aphid in cowpea. Crop Sci 28:474-476

Peter AJ, Shanower TG, Romeis J (1995) The role of plant trichomes in insect resistance: A selective review. Phytophaga 7:41-64

Pillemer EA, Tingey WM (1978) Hooked trichomes and resistance of Phaseolus vulgaris to Empoasca fabae (Harris). Entomol Exp Applic 24:83-94

Ponnusamy D, Pratap A, Singh SK et al (2014) Evaluation of screening methods for bruchid beetle (Callosobruchus chinensis) resistance in greengram (Vigna radiata) and blackgram (Vigna mungo) genotypes and influence of seed physical characteristics on its infestation. VEGETOS 27(1):60-67

Popelka JC, Gollasch S, Moore A et al (2006) Genetic transformation of cowpea (Vigna unguiculata L.) and stable transmission of the transgenes to progeny. Pl Cell Rep 25:304-312

Redden RJ, Dobie P, Gatehouse AMR (1983) The inheritance of seed resistance to Callosobruchus maculatus F. in cowpea (Vigna unguiculata L. Walp.). I. Analyses of parental, F1, F2, F3 and backcross seed generations. Aust J Agric Res 34:681-695

Riggs RD, Wang S, Singh RJ et al (1998) Possible transfer of resistance to Heterodora glycine from Glycine tomentella to Glycine max. J Nematol 30:547-552

Rosseto CJ (1989) Breeding for resistance to stink bugs. In: Pascale AJ (ed) Proceedings of the world soybean research conference IV. Assoc Argentina de la Soja Press, Buenos Aires, pp 2046-2060

Ruiz IL, Pascual MM, Omar SM et al (2012) Screening and selection of lentil (Lens Miller) germplasm resistant to seed bruchids (Bruchus spp.) Euphytica 188:153-162

Rupakala A, Rao D, Reddy L, Upadhyaya HD (2005) Inheritance of trichomes and resistance to pod borer (Helicoverpa armigera) and their association in inter-specific crosses between cultivated pigeonpea (Cajanus cajan) and its wild relative C. scarabaeoides. Euphytica 145:247-257

Salimath PM, Shahapur SC, Nijagun HG et al. (2003) Genetic analysis of pod borer tolerance and malic acid content in chickpea (Cicer arietinum L.). In: Sharma RN, Shrivastava GK, Rathore AL et al. (eds) Chickpea research for the millennium. Proceedings of the International chickpea conference, Indira Gandhi Agricultural University, Raipur, Chattisgarh, Jan 20-22, pp 81-85

Sandhu JS, Arasakesary SJ, Singh P (2005) Evaluation of chickpea (Cicer arietinum L) genotypes for cold tolerance. Indian J Pulses Res 18:171-174

Sarkar S, Bhattacharyya S (2015) Screening of greengram genotypes for bruchid (Callosobruchus chinensis L.) resistance and selection of parental lines for hybridization programme. Legume Res 38(5):704-706

Sarmah BK, Moore A, Tate W et al (2004) Transgenic chickpea seeds expressing high levels of amylase inhibitor. Mol Breeding 14:73-82 
Saxena RC (1989) Insecticides from neem. In: Arnason JT, Philogene BJR, Morand P (eds) Insecticides of plant orign, ACS Symposium Series No 387. American Chemical Society, Washington, DC, pp 110-133

Saxena KB, Lateef SS, Ariyaratne HP et al (1996) Maruca testulalis damage in determinate and indeterminate lines of pigeonpea. Internat Pigeonpea Newslett 3:91-93

Saxena KB, Chandrasena GDSN, Hettiarachchi K et al (2002) Evaluation of pigeon pea accessions and selected lines for reaction to Maruca. Crop Sci 42:615-618

Schoonhoven LM, van Loon JJA, Dicke M (2005) Insect-plant biology, 2nd edn. Oxford University Press, London

Schroeder HE, Gollasch S, Moore A et al (1995) Bean alpha-amylase inhibitor confers resistance to pea weevil (Bruchus pisorum) in transgenic peas (Pisum sativum L.) Pl Physiol 107:1233-1239

Shade RE, Schroeder HE, Pueyo J et al (1994) Transgenic pea seeds expressing a-amylase inhibitor of the common bean are resistant to bruchid beetles. BioTechnol 12:793-796

Shaheen FA, Khaliq A, Aslam M (2006) Resistance of chickpea (Cicer arietinum L) cultivars against pulse beetles. Pak J Bot 38:1224-1244

Shankar M, Sharma HC, Ramesh Babu T et al. (2012) Evaluation of chickpea genotypes for resistance to beet armyworm, Spodoptera exigua in field conditions. International Conference on Plant Health Management for Food Security, Plant Protection Association of India, Hydrabad, pp 221

Sharma HC (1998) Bionomics, host plant resistance, and management of the legume pod borer, Maruca vitrata - a review. Crop Protect 17:373-386

Sharma HC (2001) Crop protection compendium: helicoverpa armigera. Electronic compendium for crop protection. Commonwealth Agricultural Bureaux International, Wallingford, Available at: www.cabi.org/c\&c/about/contributors-p-s1

Sharma HC (2005) Strategies for Heliothis/Helicoverpa management: emerging trends and strategies for future research. Oxford and IBH, New Delhi

Sharma HC (2009) Applications of biotechnology in pest management and ecological sustainability, vol 526. CRC Press, Taylor and Francis, Boca Raton

Sharma HC (2016) Host plant resistance to insect pests in pigeonpea: Potential and limitations. Legume Perspect 11:24-28

Sharma HC, Norris DM (1991) Chemical basis of resistance in soybean to cabbage looper, Trichoplusia ni. J Sci Fd Agric 55:353-364

Sharma HC, Norris DM (1994a) Phagostimulant activity of sucrose, sterols and soybean leaf extractables to the cabbage looper, Trichoplusia ni (Lepidoptera: Noctuidae). Insect Sci Applic $15: 281-288$

Sharma HC, Norris DM (1994b) Biochemical mechanisms of resistance to insects in soybean: extraction and fractionation of antifeedants. Insect Sci Applic 15:31-38

Sharma HC, Ortiz R (2002) Host plant resistance to insects: An eco-friendly approach for pest management and environment conservation. J Environ Biol 23:11-35

Sharma HC, Pampapathy G (2004) Effect of natural plant products, Brassinolide and host plant resistance in combination with insecticides on Helicoverpa armigera (Hubner) damages in pigeonpea. Indian J Pl Protect 32(2):40-44

Sharma S, Thakur DR (2014) Biochemical basis of bruchid reistance in cowpea, chickpea and soybean genotypes. Amer J Fd Technol 9(6):318-324

Sharma S, Upadhyaya HD (2016) Pre-breeding to expand primary genepool through introgression of genes from wild Cajanus species for pigeonpea improvement. Legume Perspect 11:17-20

Sharma RP, Yadav RP (1993) Response of lentil varieties to the incidence of bean aphid (Aphis craccivora Koch) and its predatory coccinellids. LENS Newsletter 20:60-62

Sharma HC, Bhagwat VR, Saxena KB (1997) Biology and management of spotted Pod Borer, Maruca vitrata (Geyer). International Crops Research Institute for the Semi-Arid Tropics (ICRISAT), Patancheru

Sharma HC, Saxena KB, Bhagwat VR (1999) Legume pod borer, Maruca vitrata: bionomics and management. Information Bulletin 55, International Crops Research Institute for the SemiArid Tropics (ICRISAT), Patancheru 
Sharma HC, Singh BU, Artiz R et al (2001a) Host plant resistance to insects: Measurement, mechanisms and insect-plant-environment interactions. In: Ananthakrishnan TN (ed) Insects and plant defense dynamics. Oxford and IBH Publishing, New Delhi, pp 133-159

Sharma HC, Stevenson PC, Simmonds MSJ et al. (2001b) Identification of Helicoverpa armigera (Hübner) feeding stimulants and the location of their production on the pod-surface of pigeonpea [Cajanus cajan (L.) Millsp.]. Final technical report. DFID Competitive Research Facility Project [R 7029 (C)]. International Crops Research Institute for the Semi-Arid Tropics (ICRISAT), Patancheru, $85 \mathrm{p}$

Sharma HC, Pampapathy G, Reddy LJ (2003a) Wild relatives of pigeonpea as a source of resistance to the pod fly (Melanagromyza obtusa Malloch) and pod wasp (Tenaostigmodes cajaninae La Salle). Genet Resour Crop Evol 50:817-882

Sharma HC, Pampathy G, Dwivedi SL et al (2003b) Mechanisms and diversity of resistance to insect pests in wild relatives of groundnut. J Econ Entomol 96:1886-1897

Sharma HC, Ahmad R, Ujagir R (2005a) Host plant resistance to cotton bollworm/legume pod borer, Helicoverpa armigera. In: Sharma HC (ed) Strategies for Heliothis/Helicoverpa management: emerging trends and strategies for future research. Oxford and IBH, New Delhi, pp 167-208

Sharma HC, Gaur PM, Hoisington DA (2005b) Physico-chemical and molecular markers for host plant resistance to Helicoverpa armigera. In: Saxena H, Rai AB, Ahmad R et al (eds) Recent advances in Helicoverpa management indian society of pulses research and development. Indian Institute for Pulses Research, Kanpur, pp 108-121

Sharma HC, Pampapathy G, Lanka SK et al (2005c) Potential for exploitation of wild relative of chickpea, Cicer reticulatum for imparting resistance to Helicoverpa armigera. J Econ Entomol 98:2246-2253

Sharma HC, Pampapathy G, Lanka SK et al (2005d) Antibiosis mechanism of resistance to legume pod borer, Helicoverpa armigera in wild relatives of chickpea. Euphytica 142:107-117

Sharma HC, Bhagwart MP, Pampapathy G et al (2006) Perennial wild relatives of chickpea as potential sources of resistance to Helicoverpa armigera. Genet Resourc Crop Evol 53:131-138

Sharma HC, Dhillon MK, Arora R (2008) Effects of Bacillus thuringiensis delta- endotoxin-fed Helicoverpa armigera on the survival and development of the parasitoid, Campoletis chlorideae. Entomol Exp Applic 126:1-8

Sharma HC, Sujana G, Rao DM (2009) Morphological and chemical components of resistance to pod borer, Helicoverpa armigera in wild relatives of pigeonpea. Arthropod-Pl Interact 3(3):151-161

Sharma OP, Gopali JB, Yelshetty S et al (2010) Pests of pigeonpea and their management, National Centre for Integrated Pest Management. IARI Campus, New Delhi

Sharma HC, Dhillon MK, Romeis J (2011) Black aphid. In: Compendium of chickpea and lentil diseases and pests. The American Phytopathological Society, St Paul, Minnesota, p 101-103.

Silva AGD, Boiça Junior AL, Farias Paulo RS et al (2014) Non-preference for oviposition and antibiosis in bean cultivars to Bemisia tabaci biotype B (Hemiptera: Aleyrodidae). Revista Colombiana Entomolog 40(1):7-14

Simmonds MSJ (2003) Flavonoid insect-interactions: recent advances in our knowledge. Phytochemistry 64:21-30

Simmonds MSJ, Stevenson PC (2001) Effects of isoflavonoids from Cicer on larvae of Helicoverpa armigera. J Chem Ecol 27:965-977

Singh SR (1978) Resistance to pests of cowpea in Nigeria. In: Singh SR, van Emden HF, Taylor TA (eds) Pests of grain legumes: ecology and control. Academic, London, pp 267-279

Singh S (2001) Broadening the genetic base of common bean cultivars. Crop Sci 41:1659-1675

Singh BD (2002a) Plant breeding: principles and methods. Kalyani Publishers, New Delhi

Singh BB (2002b) Recent genetic studies in cowpea. In: Fatokun CA, Tarawali SA, Singh BB et al (eds) Challenges and opportunities for enhancing sustainable cowpea production. International Institute of Tropical Agriculture, Ibadan, pp 3-13

Singh KBB, Ocampo RLD (1998) Diversity for abiotic and biotic stress resistance in the wild annual Cicer species. Gen Resour Crop Evol 45:9-17 
Singh KJ, Singh OP (1990) Efficacy and economics of some synthetic pyrethroid insecticides for the control of tur podfly, Melanagromyza obtusa (Malloch). Indian J of Entomol 52(1):31-34

Singh KB, Weigand S (1994) Identification of resistant sources in Cicer species to Liriomyza cicerina. Genet Resour Crop Evol 41:75-79

Singh KB, Kumar J, Haware MP et al (1990) Disease and pest resistance breeding: which way to go in the nineties? In: Chickpea in the nineties, Proceedings of the second International workshop on chickpea improvement, 4-8 Dec, Andhra Pradesh, India: International Crops 805 Research Institute for semi-arid Tropics (ICRISAT) Patancheru 502324, International Center for Agricultural Research in Dry Areas (ICARDA), p 807 233-238

Singh O, Gowda CLL, Sethi SC et al. (1991) Inheritance and breeding for resistance to Helicoverpa armigera, pod borer in chickpea. In: Golden jubilee symposium on genetic research and evaluation, current trends and next fifty years. Indian Society of Genetics and Plant Breeding, Indian Agricultural Research Institute, 12-15 Feb, New Delhi, p 121

Singh BB, Asante SK, Jackai LEN et al (1996) Screening for resistance to parasitic plants, virus, aphid and bruchid. Annual Report 1996, project 11, Cowpea-cereals system improvements in the dry savannas, International Institude of Tropical Agriculture, Ibadan

Singh O, Sethi SC, Lateef SS et al (1997) Registration of ICCV 7 chickpea germplasm. Crop Sci 37(1):295

Sison MJ, Cowgil E, Lateef SS (1996) Identification of antibiotic and antixenotic resistance to Helicoverpa armigera (Hub.) (Lepidoptera: Noctuidae) in chickpea. J Econ Entomol 89:224-228

Smith CM (2005) Plant resistance to arthropods- molecular and conventional approaches. Springer Verlag, Dordrecht

Solleti SK, Bakshi S, Purkayastha J et al (2008) Transgenic cowpea (Vigna unguiculata) seeds expressing a bean $\alpha$-amylase inhibitor 1 confer resistance to storage pests, bruchid beetles. Pl Cell Rep 27:1841-1850

Somta P, Talekar NS, Srinives P (2006) Characterization of Callosobruchus chinensis (L.) resistance in Vigna umbellata (Thunb.) Ohwi \& Ohashi. J Stored Prod Res 42:313-327

Somta C, Somta P, Tomooka N et al (2008) Characterization of new sources of mungbean (Vigna radiata (L) Wilczek) resistance to bruchids, Callosobruchus spp (Coleoptera: bruchidae). J Stored Prod Res 44:316-321

Song F, Swinton SM, DiFonzo C et al. (2006) Profitability analysis of soybean aphid control treatments in three northcentral states. Department of Agricultural Economics, Staff Paper 24 Michigan State University

Soundararajan, RP, Chitra N, Ramasamy M (2010) Host Plant Resistance to insect pests of urdbean and mungbean. In: National workshop on paradigm shifts in research on crop resistance to pests, Annamalai University, Annamalai Nagar, March 4-5 Mar, p 57-58

Soundararajan RP, Chitra N, Geetha S (2013) Host plant resistance to insect pests of grain legumes - A Review. Agri Rev 34(3):176-187

Sousamajer MJD, Hardie DC, Turner NC (2007) Bean $\alpha$-Amylase inhibitors in transgenic peas inhibit development of pea weevil larvae. J Econ Entomol 100:1416-1422

Sreelatha E, Gowda CLL, Gaur TB et al. (2003) Stability of Resistance to Helicoverpa armigera in chickpea In: Sharma RN, Shrivastava, GK, Rathore AL et al. (Ed) Chickpea research for the millennium: proceedings of the international chickpea conference, Raipur, 20-22 Jan, pp 138-142

Sreelatha E, Gowda CLL et al (2008) Genetic analysis of pod borer (Helicoverpa armigera) resistance and grain yield in desi and kabuli chickpeas (Cicer arietinum) under unprotected conditions. Internat J Genet 68(4):406-413

Srivastava CP, Joshi N (2011) Insect pest management in pigeonpea in Indian scenario: A critical review. Indian J Entomol 73(1):63-75

Srivastava CP, Srivastava RP (1989) Screening for resistance to gram pod borer, Heliothis armigera (Hubner) in chickpea (Cicer arietinum L.) genotypes and observations on its mechanism of resistance in India. Insect Sci Applic 10:255-258 
Stevenson PC, Green PWC, Simmonds MSJ et al (2005) Physical and chemical mechanisms of plant resistance to Helicoverpa: Recent research on chickpea and pigeonpea. In: Sharma HC (ed) Helicoverpa/Heliothis management: emerging trends and strategies for the future research. Oxford \&IBH, New Delhi, pp 215-228

Sudha M, Karthikeyan A, Anusuya P et al (2013) Inheritance of resistance to mungbean yellow mosaic virus (MYMV) in inter and intra specific crosses of mungbean (Vigna radiata). Amer J Pl Sci 4:1924-1927

Sujana G, Sharma HC, Manohar Rao D (2008) Antixenosis and antibiosis components of resistance to pod borer Helicoverpa armigera in wild relatives of pigeonpea. Internat J Trop Insect Sci 28(4):191-200

Sujana G, Sharma HC, Manohar Rao D (2012) Pod surface exudates of wild relatives of pigeonpea influence the feeding preference of the pod borer, Helicoverpa armigera. Arthropod Pl Interact 6(2):231-239

Sunitha V, Ranga Rao GV, Vijaya Lakshmi K et al (2008a) Morphological and biochemical factors associated with resistance to Maruca vitrata (Lepidoptera: Pyralidae) in short duration pigeonpea. Internat J Trop Insect Sci 28:45-52

Sunitha V, Vijaya Laksmi K, Ranga Rao GV (2008b) Screening of pigeonpea genotypes against Maruca vitrata (Geyer). J Fd Legume 21:193-195

Taggar GK, Gill RS (2012) Preference of whitefly, Bemisia tabaci, towards pi genotypes: role of morphological leaf characteristics. Phytoparasitica 40:461-474

Taggar GK, Singh RG, Gupta AK et al (2012) Fluctuations in peroxidase and catalase activities of resistant and susceptible black gram (Vigna mungo (L.) Hepper) genotypes elicited by Bemisia tabaci (Gennadius) feeding. Pl Signal Behav 7(10):1321-1329

Talekar NS, Lin CL (1992) Characterization of Callosobruchus chinensis (Coleoptera: bruchidae) resistance in mungbean. J Econ Entomol 85:1150-1153

Taran B, Michaels TE, Pauls KP (2002) Genetic mapping of agronomic traits in common bean (Phaseolus vulgaris L.) Crop Sci 42:544-446

Tarver MR, Shade RE, Shukle RH et al (2007) Pyramiding of insecticidal compounds for control of the cowpea bruchid (Callosobruchus maculatus F.) Pest Manag Sci 63:440-446

Teshome A, Mendesil E, Geleta M et al (2015) Screening the primary gene pool of field pea (Pisum sativum L. subsp. sativum) in Ethiopia for resistance against pea weevil (Bruchus pisorum L.) Genet Resour Crop Evol 62:525-538

Thu TT, Mai TTX, Dewaele E et al (2003) In vitro regeneration and transformation of pigeonpea [Cajanus cajan (L.) Millsp.] Mol Breeding 11:159-168

Tilmon KJ, Hodgson EW, O'Neal ME et al (2011) Biology of the soybean aphid, Aphis glycines (Hemiptera: Aphididae) in the United States. J Integ Pest Manag 2(2):e1-e7

Timko MP, Singh BB (2008) Cowpea, a multifunctional legume. In: Moore PH, Ming R (eds) Genomics of tropical crop plants. Springer, New York, pp 227-258

Ujagir R, Khare BP (1988) Susceptibility of chickpea cultivars to gram pod borer, Heliothis armigera (Hubner). Ind J Pl Protect 16(1):45-49

Usha Rani P, Jyothsna Y (2010) Biochemical and enzymatic changes in rice as a mechanism of defense. Acta Physiol Pl 32:695-701

Usua EJ, Singh SR (1979) Behaviour of cowpea pod borer, Maruca testulalis Geyer. Nigerian. J Entomol 3:231-239

Valdez PC (1989) Host plant resistance in cowpea, Vigna unguiculata (L) Walp. var. unguiculata, to the pod borer, Maruca testulalis (Geyer) (Lepidoptera: Pyralidae). Philippines University College, Los Banos

van Emden HF, Ball SL, Rao MR (1988) Pest and disease problems in pea, lentil, faba bean, and chickpea. In: Summerfield RJ (ed) World Crops: cool season food legumes. Kluwer, Dordrecht, pp 519-534

van Rheenen HA (1992) Biotechnology and chickpea breeding. Internat Chickpea Newsl 26:14-17

Verulkar SB, Singh DP, Bhattacharya AK (1997) Inheritance of resistance to pod fly and pod borer in the inter-specific cross of pigeonpea. Theor Appl Genet 95:506-508 
Villareal JM, Hautea DM, Carpena AL (1998) Molecular mapping of the bruchid resistance gene in mungbean Vigna radiata L. Philippine J Crop Sci 23(supplement 1):1-9

Wang XB, Fang YH, Lin SZ (1994) A study on the damage and economic threshold of the soybean aphid at the seedling stage. Pl Prot 20:12-13

War AR, Paulraj MG, War MY et al (2013) Defensive responses in groundnut against chewing and sap sucking insects. J Pl Growth Regul 32:259-272

Weigand S, Lateef SS, El Din Sharaf N et al (1994) Integrated control of insect pests of cool season food legumes. In: Muehlbauer EJ, Kaiser WJ (eds) Expanding the production and use of cool season food legumes. Kluwer, Dordrecht, pp 679-694

Williams CB, Chambliss OL (1980) Out crossing in southern pea. Hortic Sci 15:179

Yang TJ, Kim DH, Kuo GC et al (1998) RFLP marker-assisted selection in backcross breeding for introgression of the bruchid resistance gene in mungbean. Korean J Breed 30:8-15

Yoshida M, Cowgill SE, Wightman JA (1995) Mechanisms of resistance to Helicoverpa armigera (Lepidoptera: Noctuidae) in chickpea - role of oxalic acid in leaf exudates as an antibiotic factor. J Econ Entomol 88:1783-1786

Yoshida M, Cowgill SE, Wightman JA (1997) Roles of oxalic and malic acids in chickpea trichome exudates in host-plant resistance to Helicoverpa armigera. J Chem Ecol 23:1195-1210

Young ND, Kumar L, Menancio-Hautea D et al (1992) RFLP mapping of a major bruchid resistance gene in mungbean (Vigna radiata, L. Wilczek). Theor Appl Genet 84:839-844 